\title{
Mechanisms Underlying the Action and Synergism of Trastuzumab and Pertuzumab in Targeting HER2-Positive Breast Cancer
}

\author{
Babak Nami ${ }^{\dagger}$ (), Hamid Maadi ${ }^{\dagger}$ and Zhixiang Wang * \\ Signal Transduction Research Group, Department of Medical Genetics, Faculty of Medicine and Dentistry, \\ University of Alberta, Edmonton, AB T6G 2H7, Canada; namimoll@ualberta.ca (B.N.); \\ hmaadi@ualberta.ca (H.M.) \\ * Correspondence: zhixiang.wang@ualberta.ca; Tel.: +1-780-492-0710; Fax: +1-780-492-1998 \\ + These authors contributed equally to this manuscript.
}

Received: 8 August 2018; Accepted: 18 September 2018; Published: 20 September 2018

\begin{abstract}
Human epidermal growth factor receptor (HER) 2 (HER2) is overexpressed in 20-30\% of breast cancers. HER2 is a preferred target for treating HER2-positive breast cancer. Trastuzumab and pertuzumab are two HER2-targeted monoclonal antibodies approved by the Food and Drug Administration (FDA) to use as adjuvant therapy in combination with docetaxel to treat metastatic HER2-positive breast cancer. Adding the monoclonal antibodies to treatment regimen has changed the paradigm for treatment of HER2-positive breast cancer. Despite improving outcomes, the percentage of the patients who benefit from the treatment is still low. Continued research and development of novel agents and strategies of drug combinations is needed. A thorough understanding of the molecular mechanisms underlying the action and synergism of trastuzumab and pertuzumab is essential for moving forward to achieve high efficacy in treating HER2-positive breast cancer. This review examined and analyzed findings and hypotheses regarding the action and synergism of trastuzumab and pertuzumab and proposed a model of synergism based on available information.
\end{abstract}

Keywords: trastuzumab; pertuzumab; breast cancer; HER2; HER family receptors; mechanisms; synergism

\section{Introduction}

There are four members in the HER receptor family. They are epidermal growth factor (EGF) receptor (EGFR/HER1/ErbB1, HER2/ErbB2, HER3/ErbB3, and HER4/ErbB4 [1,2]. All HER receptors, except for HER4, have been implicated in breast cancer [3-12]. EGFR, HER2 and HER3 are overexpressed in $30-40 \%, 20-30 \%$ and $20 \%$ of breast cancer cases, respectively [4,11,13-17]. Targeting HER2 in treating HER2-positive breast cancer has proven to be an effective therapeutic strategy $[18,19]$. Since approval by the FDA in 1998, trastuzumab, a HER2 antibody, has changed the paradigm for treating HER2-positive breast cancer $[19,20]$. However, acquired trastuzumab resistance has developed with time, which needs to be overcome [19,21,22]. Pertuzumab is another HER2-targeting antibody. Its recent approval by the FDA to be used in combination with trastuzumab and docetaxel has significantly improved the outcome of the patients with metastatic HER2-positive breast cancer [11,19,23-25]. It has been shown recently that adding pertuzumab to adjuvant trastuzumab and chemotherapy significantly improves the outcomes among patients with HER2-positive early breast cancer [26]. However, the lack of a good understanding of the mechanisms underlying the action and synergism of trastuzumab and pertuzumab severely limit its application and efficacy. Indeed, despite these achievements, the persisting high toll of deaths necessitates newer therapies and combinations [27]. 
In this review, we will focus on the reported mechanisms and hypotheses underlying the action and synergism of trastuzumab and pertuzumab in targeting HER2-positive breast cancer.

\section{The Roles of HER Receptors in Breast Cancers}

Breast cancers are classified as five intrinsic subtypes based on their gene expression profiles revealed by microarray: luminal-like subtypes $\mathrm{A}$ and $\mathrm{B}$ (expression of hormone receptors and luminal cytokeratins 8 and 18), basal-like (also called triple-negative breast cancer (TNBC), typically with no expression of estrogen receptors (ER), progestin receptors, and HER2), HER2-positive (HER2+), and normal-like $[28,29]$. HER receptors have been implicated in the development of many types of human cancers, especially breast cancer. Overactivation of HER receptors is mostly due to overexpression driven by gene amplification, but also could be due to the truncation of the extracellular domain, mutation in kinase domain, or co-expression of HER receptor ligands. The overactivation of HER receptors drives cancer development $[5,30,31]$.

Overexpression of EGFR is observed in $20-30 \%$ of breast carcinoma. While high percentage of HER2-positive breast cancer cells also overexpress EGFR, approximately $50 \%$ of TNBC cells overexpress EGFR $[12,30,32]$. Overexpression of EGFR has been frequently associated with large tumor size and poor clinical outcomes [30,32-34].

ErbB2 overexpression occurs in 20-30\% of breast cancers and ovarian cancers [11,13-16,30,35]. HER2 mutations are observed in approximately $1.6 \%$ of breast cancer patients [36]. Patients whose breast tumors overexpress the ErbB2 have a significantly lower survival rate and a shorter period before relapse than patients without ErbB2 overexpression [13,35,37]. Moreover, ErbB2 overexpression has been positively correlated with lymph node metastasis in breast cancers [38,39]. Overexpression of HER2 also increases tumorigenicity in nude mouse xenograft models [40-42]. ErbB receptors have been the top choice for breast cancer therapies $[6,8,16,43]$.

Overexpression of ErbB3 occurs in about 20\% of breast cancers [15]. Overexpression is mostly due to increased transcription $[15,44]$. Overexpression of HER3 alone does not promote anchorage-independent growth; however, when expressed together with HER2, HER3 strongly stimulates cell growth [30,45]. Different from other HER receptors, both oncogenic and tumor-suppressor functions have been reported for HER4 [46-49].

\section{HER Receptors and Cell Signaling}

There are more than 60 receptor tyrosine kinases (RTKs) that have been identified in the human genome [50]. Like other RTKs, HER receptors are single transmembrane proteins which have an N-terminal extracellular domain, a transmembrane helix, and a cytoplasmic domain [51]. The extracellular domain contains four subdomains, including the ligand binding subdomains (domain I and III), and receptor dimerization subdomains (domain II and IV). The intracellular domain is composed of a tyrosine kinase domain and a C-terminal regulatory domain (Figure 1) [52].

EGFR, a $170 \mathrm{kD}$ single polypeptide chain, is the prototype of the HER family receptor [53-58]. While EGFR and HER4 are fully functional RTKs capable of signaling both as a homo- and heterodimers following the binding to various ligands, the other two members, including HER2 and HER3, are different. HER2 is an orphan receptor without a ligand and HER3 is a lack of kinase activity. However, through ligand-induced heterodimerization, all HER receptors could be fully activated to mediate cell signaling [2,16,59-73]. 


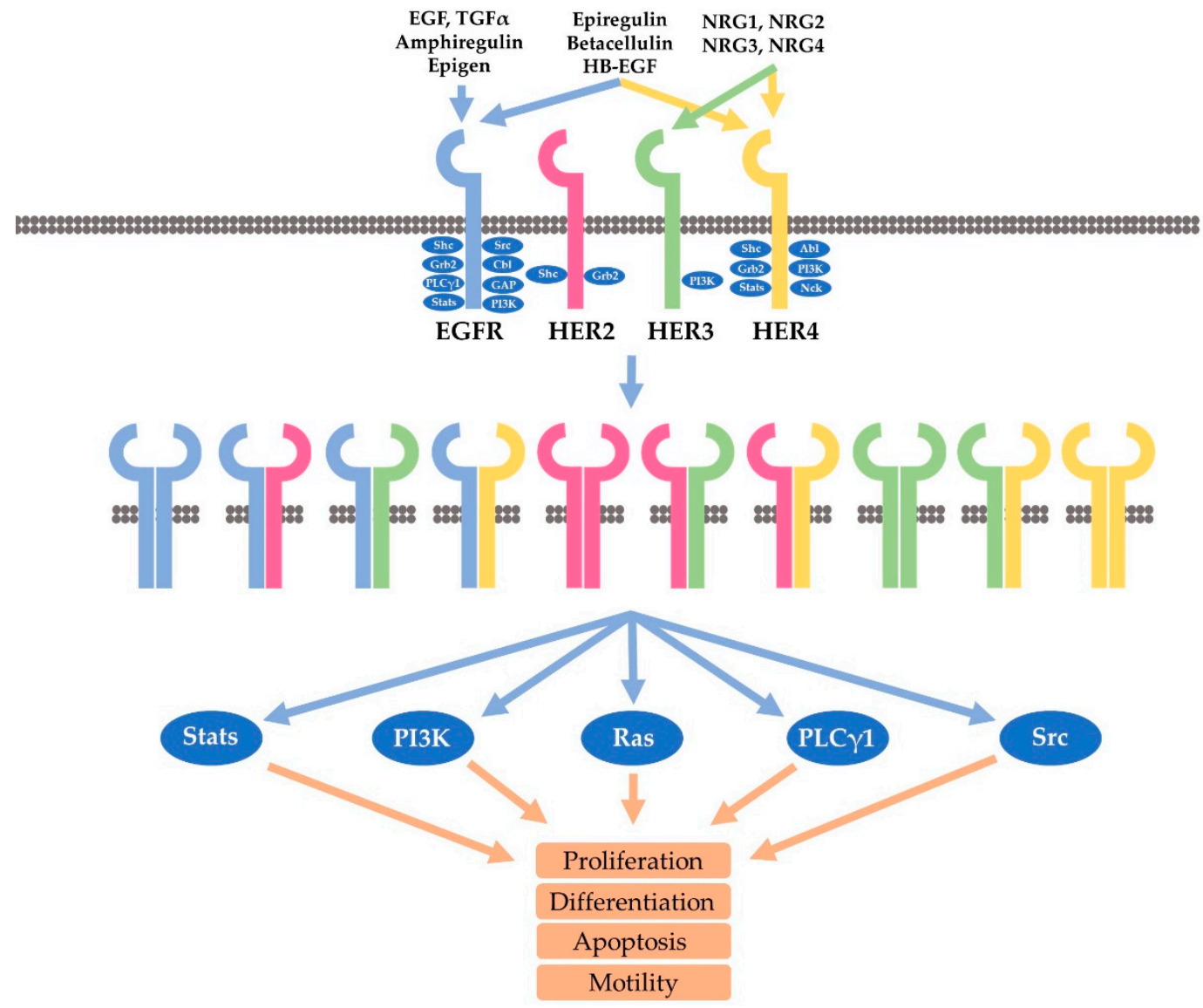

Figure 1. The activation of HER receptors and the downstream signaling cascades. Four members of HER receptors interact with 11 ligands, which results in the formation and the activation of 10 different homo- and heterodimers. Activated HER receptors promote many signaling cascades affecting many key biological outcomes.

Besides EGF, another ten ligands have been identified to bind to and stimulate HER receptors. These ligands form the EGF family of peptide growth factors and are subdivided into three groups based on their binding partners (Figure 1). EGF, epigen (EPG), amphiregulin (AR), and transforming growth factor (TGF) form one group that specifically binds to EGFR. HB-EGF, epiregulin (EPR), and betacellulin (BTC) form the second group that binds to both EGFR and HER4. The four neurogulins, including NRG1, NRG2, NRG3, and NRG4, form the third group that binds to HER4. However, NRG and NRG2 also bind to HER3 (Figure 1) [5,30,31,74-76]. Through the distinctive binding specificity and affinity, each ligand contributes in a unique manner to regulate the activation and signaling of the four HER receptors [2].

Our understanding of HER receptor dimerization has been greatly enhanced due to the determination of the structures of the HER receptor extracellular domains. So far, the structures of all HER receptors without ligand have been determined. In addition, the structures of ligand-bound EGFR and HER4 have also been determined. Many structures of HER receptors binding to antibodies or antibody mimics have also been revealed $[51,77,78]$. With the support of other evidence, a comprehensive picture regarding ligand-receptor interaction and HER receptor dimerization have emerged. In total, ten different homo- and heterodimers are formed by four HER receptors (Figure 1) [1,79].

Structure studies indicate that the conformations of the receptors can only exist in two forms: a tethered form and an extended form. In the tethered form the receptor is unable to dimerize due to the buried dimerization element. However, in the extended form the dimerization elements of the receptor are fully exposed to allow the receptor dimerization. It has been demonstrated that the rigid 
nature of the receptor extracellular domains restricted or "clicked" the receptors only to these two forms $[51,78]$.

In is significant and interesting to find that HER2 extracellular domains are already in extended form in the absence of ligands. The subdomains I and III of HER2 extracellular domain interact directly to stabilize HER2 to the extended form. The close interaction between subdomain I and III leaves no space for a ligand in between, Therefor, HER2 is an orphan receptor by nature [79]. Thus, HER2 maintains a ligand-independent and constitutively activated conformation. Indeed, HER2 spontaneously forms homodimers when overexpressed in cells, and all the other HER receptors dimerize preferably with HER2 [1,30]. Moreover, the overexpression of HER2 (but not the other HER receptors) transforms cells, and HER2 overexpression is associated with poor prognosis in breast cancer [79].

On the other hand, HER3 homodimer is generally believed as non-functional due to lack of kinase activity. However, HER3 possesses very low kinase activity (1/1000th kinase activity of EGFR) and thus it is still possible that HER3 homodimers may be functional [30].

Through homo- or heterodimerization, all HER receptors are activated, which induces the phosphorylation of multiple tyrosine residues in the C-terminal regulatory region. Various studies including large-scale phosphoproteomic screening has identified more than 100 proteins that potentially bind to HER receptors (Figure 1) [12,30,80-88]. Several interesting features are revealed through the mapping of these tyrosine phosphorylation residues. Both EGFR and HER4 bind to many different downstream proteins. EGFR binds to Grb2, Shc, Src, PLC- $\gamma 1$, Crk, Stat5, Ptp-2c, and SHP1. HER4 binds to Syk, RasA1, Abl, Crk and Vav2, and Grb2. However, the signaling pathways linked to HER2 and HER3 are very specific and limited. HER3 contains multiple phosphor tyrosine residues that bind to p85, and as such, HER3 strongly activate the PI3K-Akt pathway. On the other hand, HER2 is mostly engaged in Shc/Grb2-mediated activation of Erk pathways. Due to the distinctive binding to various downstream signaling proteins, the heterodimerization of HER receptors allows the activation of more signaling cascades than the homodimer of HER receptors. Based on the binding specificity, it is likely that the HER2 homodimer will mostly stimulate the activation of the Ras-ERK pathway, and the HER2-EGFR heterodimer may function similarly to EGFR homodimer. However, the HER2-HER3 heterodimer could be much more powerful than either the HER2 homodimer or HER3 homodimer because the HER2-HER3 heterodimer could fully activate all available HER2 and HER3 receptors, and the HER2-HER3 heterodimer could strongly activate the PI3K-Akt pathway in addition to the Ras-ERK pathway. Indeed, much research has linked the PI3K-Akt pathway to HER2-HER3 signaling and to HER2-positive breast cancer.

PI3K could be activated by HER receptors either directly through the interaction between its p $85 \alpha$ subunit and HER receptor or indirectly through the activated Ras $[89,90]$. A negative regulator of PI3K is the phosphatase and tensin homologue deleted on chromosome 10 (PTEN). The function of PI3K in cell survival is mediated by Akt, a serine threonine (Thr) kinase [91-93]. Akt contains an $\mathrm{N}$-terminal Pleckstrin homology (PH) domain, a C-terminal regulatory domain, and a central kinase domain. Akt is recruited to the plasma membrane by the interaction of its SH3 domain with PIP3 (generated by PI3K), which induces the conformational change of Akt to allow the phosphorylation of its Thr 308 by membrane-localized 3-phosphoinositide-dependent kinase 1 (PDK-1). Following the additional phosphorylation of Ser 473 by rapamycin complex 2 (mTORC2), Akt is fully activated. Akt controls various cellular functions by phosphorylating several intracellular proteins, including the glycogen synthase kinase 3 (GSK3), the BCL2-associated agonist of cell death (BAD), and forkhead box $\mathrm{O}$ transcription factors (FoxO). Akt also activates mTORC1, which protects the cell from undergoing apoptosis [92-94].

\section{Mechanisms Underlying the Action of Trastuzumab}

HER2 is an attractive therapeutic target for the treatment of HER2-positive breast cancer $[6,8]$. As a humanized recombinant monoclonal antibody to HER2, trastuzumab binds to HER2 domain IV 
that is close to the HER2 juxtamembrane region. Trastuzumab is the first HER2-targeted therapy that was approved by the FDA for the treatment of metastatic breast cancer. It selectively exerts antitumor effects in HER2-positive breast cancer patients [6,8].

Although many mechanisms have been proposed for its antitumor activity, the exact mechanisms remain unknown. As summarized by several earlier reviews [6,8,95], several mechanisms including both intracellular and extracellular mechanisms are proposed for the action of trastuzumab (Figure 2A).

Antibody-dependent cell-mediated cytotoxicity (ADCC) is identified as the extracellular action of trastuzumab. The Fc receptor on immune effector cells, principally natural-killer (NK) cells, recognizes the $F_{c}$ portion of trastuzumab in the targeted cancer cell and attacks the cancer cells. Action through ADCC has been supported by much evidence as a major mechanism of trastuzumab [96-104]. This mechanism is also supported by recent studies [101,104]. Recent studies in this area have focused on how to enhance the ADCC mediated by trastuzumab. It is reported that trastuzumab-induced ADCC could by augmented by enhancing NK cell activities [105,106], by modifying the antibody itself [107-109], and by inhibitors to various proteins including caspase [110], CD112R and TIGIT [111], Histone deacetylase (HDAC), and Adams [112]. Moreover, chemotherapeutic drug including Tanxanes [113] and tyrosine kinase inhibitors [114,115] are also found to enhance trastuzumab-mediated ADCC.

A

\section{Mechanisms Underlying the Action of Trastuzumab}

\begin{tabular}{|c|c|c|}
\hline $\begin{array}{l}\text { Extraxcellular } \\
\text { action }\end{array}$ & ADCC & $\begin{array}{l}\text { Well } \\
\text { supported }\end{array}$ \\
\hline \multirow{4}{*}{$\begin{array}{l}\text { Intracellular } \\
\text { action }\end{array}$} & $\begin{array}{l}\text { Inhibition of } \\
\text { HER2-mediated } \\
\text { cell signaling }\end{array}$ & Controversy \\
\hline & $\begin{array}{l}\text { Inhibition of } \\
\text { HER2 cleavage }\end{array}$ & Limited data \\
\hline & $\begin{array}{l}\text { Inhibition of } \\
\text { angiogenesis }\end{array}$ & Limited data \\
\hline & $\begin{array}{l}\text { Inhibition of } \\
\text { DNA damage } \\
\text { repair }\end{array}$ & Limited data \\
\hline
\end{tabular}

B

Mechanisms underlying the Action of Pertuzumab

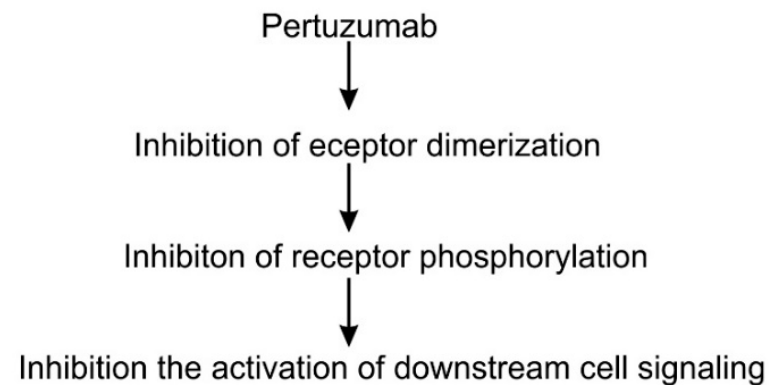

Figure 2. The potential mode of action of trastuzumab and pertuzumab. (A) Five mechanism have been proposed and partially tested regarding the action of trastuzumab. (B) The mechanism of pertuzumab is likely through the inhibition of HER2 dimerization and activation.

Many intracellular mechanisms have been proposed for trastuzumab action; however, the data are controversial [83]. The proposed intracellular mechanisms include: (1) inhibition of intracellular signal 
transduction leading to cell proliferation. While this mechanism has been the basis for developing trastuzumab and has been referred by most reviews $[6,116,117]$, this mechanism is not supported by experimental data. Most experimental data indicate that trastuzumab does not inhibit, but under certain conditions actually stimulates HER2 phosphorylation $[6,8,95,118,119]$. The data regarding the effects of trastuzumab on HER2 dimerization, HER2-mediated activation of Akt, Erk and other signaling proteins [120-123], and HER2 endocytosis/downregulation [120-123] are all controversial. Some data suggest that trastuzumab may affect cell signaling and cell cycle progression by regulating gene expression through an undefined mechanism $[118,124]$. (2) Inhibition of the proteolytic cleavage of HER2 extracellular domain. p95HER2 fragments are truncated HER2 proteins characterized by the lack of extracellular domain (ECD), but still possessing tyrosine kinase activity [125-129]. p95HER2 fragments arise by two different mechanisms: (i) proteolytic shedding/cleavage of p185HER2 by zinc-containing metalloproteinase, including A disintegrin and metalloproteinases (ADAM) and matrix metalloproteinase (MMP) family members [130-132]; and (ii) Alternative initiation of translation. p95HER2 could be generated by alternative initiation of translation from methionines located near the transmembrane domain of the full-length molecule [133]. Breast cancer patients expressing p95HER2 are more likely to develop nodal metastasis [134] and have worse prognoses than those predominantly expressing the full-length receptor [135]. It was reported that trastuzumab blocked both basal and induced cleavage of p95HER2 [126]. (3) Inhibition of DNA repair. Chemo- and radiotherapies induce DNA damage in treated cancer cells and cancer cells may minimize this damage by repairing the damaged DNA. Some early studies suggest that trastuzumab partially blocks the repairing of damaged DNA [136-138]. However, all these data were published in the 1990s from one research group. (4) Inhibition of angiogenesis. Cancer cells promote angiogenesis to support tumor growth. Trastuzumab was shown in a preclinical murine xenograft tumor model to inhibit the angiogenesis $[139,140]$.

\section{Mechanisms Underlying Trastuzumab Resistance}

Since its introduction in 1999, trastuzumab has changed the paradigm of treating metastatic HER2-positive breast cancer patients. While it significantly improved the treatment, the resistance, both innate and acquired, has posed big challenge [141,142]. The overall response rate is about $50 \%$ with a significant percentage (approximately 40\%) of metastatic patients demonstrating primary resistance. Moreover, most of the patients who initially responded to trastuzumab treatment quickly acquired resistance. Scientific communities have been studying the mechanisms underlying the resistance in the hope of overcoming this it [142-144].

Many resistance mechanisms have been identified. The resistance may arise due the altered HER2 expression status of the cancer cells $[145,146]$. The resistance may also arise due the alteration of HER2 molecule structures, such as proteolytic truncation of HER2 extracellular domain, which prevents the binding of trastuzumab to the truncated but constitutively activated HER2 [127,128,147,148]. Activation of other HER receptors such as EGFR, which compensate the lost HER2 signaling due to trastuzumab inhibition $[149,150]$, or activation of HER2 through a mechanism that is not sensitive to trastuzumab $[151,152]$. Constitutive activation of downstream signaling pathways due to mutations are also a major mechanism for trastuzumab resistance. The most prominent case is the constitutive activation of PI3K-Akt-mTor pathway due to gain of function mutation of PI3K, and the loss of function of PTEN [153-159]. Some other mechanisms are also reported, including FC $\gamma$ receptor polymorphism [160,161], miRNAs [162,163], and Mucin 4 expression induced by TNF $\alpha$ [164].

As HER2/HER3 heterodimer-mediated activation of PI3K-Akt-mTor has been considered the most important signaling pathway driving the development of breast cancer, and constitutive activation of this pathway identified as a major resistant mechanisms for trastuzumab resistance, combined inhibition of both HER2 and PI3K-Akt-mTor has been explored to overcome trastuzumab resistance $[165,166]$. Most research has demonstrated that additional inhibition of PI3K-Akt-mTor could overcome trastuzumab resistance in HER2-positive breast cancers [156,167-170]. 


\section{Mechanisms Underlying the Action of Pertuzumab}

As a fully humanized recombinant monoclonal antibody, pertuzumab represents a new class of agents that inhibit HER2 dimerization [19] (Figure 2B). Pertuzumab specifically interacts with the subdomain II of HER2 extracellular domain, sterically blocking a binding pocket necessary for receptor dimerization, thus blocking HER2 dimerization mediated by the HER2 dimerization domain [77]. Indeed, the same research showed that pertuzumab blocked heregulin-induced heterodimerization between HER2 and HER3 [77]. Inhibition of dimerization will lead to the blocking of HER2 activation and HER2-mediated downstream signaling [19]. This understanding is mostly based on important early research [171]. This research showed that pertuzumab blocks the association of HER2 and HER3, diminishes ligand-activated HER2 signaling including Erk activation, and inhibits the growth of human breast cancer cell lines only in the presence of ligand (heregulin) [171]. This research was conducted with breast cancer cell lines that co-express both HER2 and HER3 in the context of heregulin stimulation. Subsequent brief research suggests the synergistic effect of trastuzumab and pertuzumab on breast cancer survival, but showed that pertuzumab alone is less effective in blocking Akt phosphorylation than trastuzumab and both antibodies have no effect on Erk phosphorylation in BT474 cells [172]. It was further reported that pertuzumab disrupts EGF-induced heterodimerization of HER2 and EGFR in ovarian cancer cells, expressing both EGFR and HER2. Pertuzumab also inhibits in vitro and in vivo growth of the same ovarian cancers [173]. Moreover, pertuzumab can abrogate the inhibitory effect of HER2 on the degradation of HER3 [174]. A recent study showed that both trastuzumab and pertuzumab inhibit NRF2 function in ovarian cancers and the combination of the antibodies produces more potent effects than a single antibody alone [175]. In summary, while the data regarding the mode of action of pertuzumab is quite limited, the available data mostly support the role of pertuzumab in blocking the heterodimerization of HER2, which in turn blocks the activation of HER2- and HER3-mediated signal transduction pathways leading to cancer cell proliferation and survival.

Pertuzumab was approved by the FDA in 2012 to be used in combination with trastuzumab and docetaxel for treating metastatic breast cancer patients. This approval is based on the clinic trial results reported the same year by the CLEOPATRA Study Group [167]. This treatment regime has significantly improved the outcome of the patients with metastatic HER2-positive breast cancer and is now the standard first-line treatment for HER2-positive metastatic breast cancer [11,19,23-25,176]. It has also recently been shown that adding pertuzumab to adjuvant trastuzumab and chemotherapy results in better outcomes among patients with HER2-positive early breast cancer [26]. As pertuzumab has only been introduced for a short period, there is not enough data and research regarding the resistance. However, the persistent high death toll and lower response rate among patients previously treated with trastuzumab suggests the presence of resistance and poses challenges $[27,177]$.

\section{The Mechanisms Underlying the Synergism of Trastuzumab and Pertuzumab}

While a better outcome is achieved by the combination of pertuzumab and trastuzumab, very little is known regarding the mechanisms underlying the synergism of trastuzumab and pertuzumab, which hampers the effective application of these two antibodies.

Several mechanisms have been proposed to explain the observed synergism of trastuzumab and pertuzumab in treating HER2-positive cancers, including breast cancer, ovarian cancer, non-small cell lung cancer, and gastric cancer [178-181]. These mechanisms include: (1) the synergism due to the different functions of these two antibodies in targeting HER2-positive cancer cells (reviewed in [182]); (2) synergism due to composition-independent inhibitory effects of the combination of the two antibodies in a wide range of HER2/HER3 composition [183]; and (3) synergism of trastuzumab and pertuzumab partly due to the enhanced binding affinity towards the HER2 molecule that originated from the cooperative interactions between the two antibodies [184]. While the first one is supported by some experimental data, the other two mechanisms are purely based on computational models. Thus, the mechanism one will be discussed in more detail. 
Many different functions have been attributed to trastuzumab and pertuzumab, and all of them could be used to explain the synergism of the two antibodies. One favored theory is that trastuzumab inhibits the homodimerization of HER2 and the downstream signaling pathways activated by HER2 homodimer, whereas pertuzumab preferentially blocks the heterodimerization of HER2 with EGFR, HER3, and HER4, and the downstream signaling pathways activated by HER2 heterodimers (Figure 3A) [182,185]. This theory is supported by some research data. It was reported that trastuzumab, not pertuzumab, disrupts ligand-independent signaling mediated by the HER2 homodimer [186]. It was also shown that trastuzumab inhibited ligand-independent HER2 and HER3 interaction [187]. On the other hand, pertuzumab prevents ligand-induced dimerization of HER2 with HER3 [171,174,186,188].

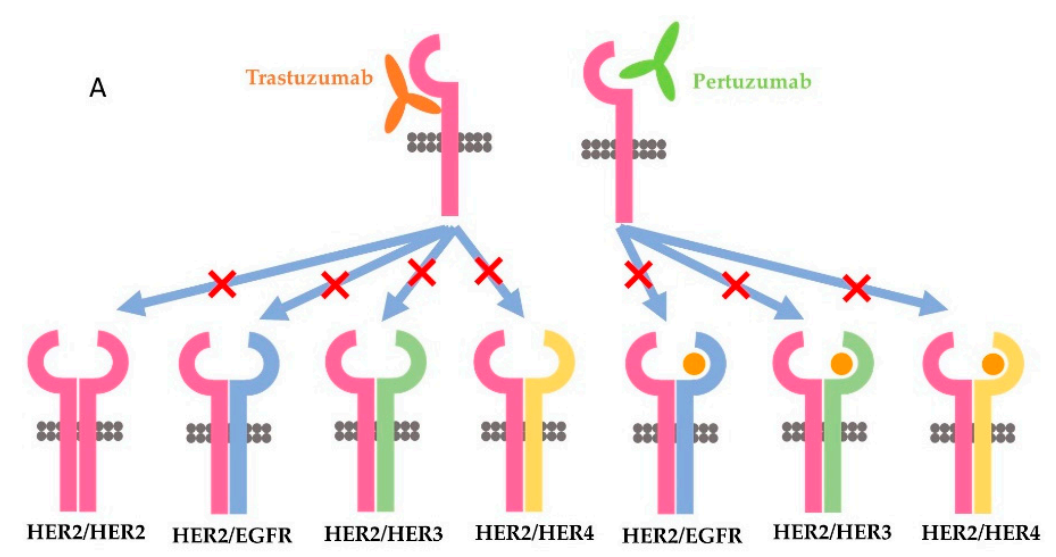

B

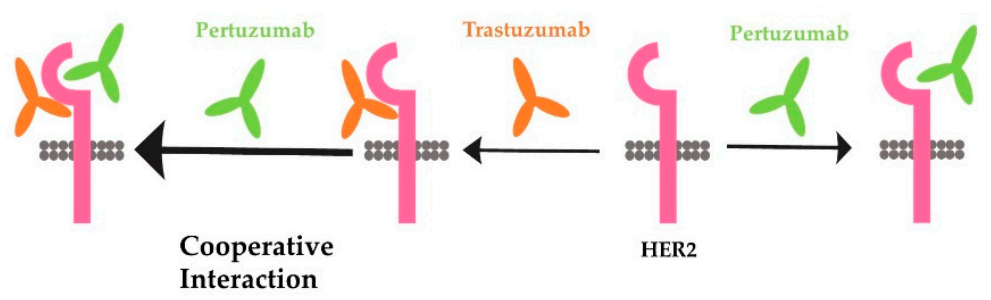

Figure 3. Proposed models illustrating the synergism of trastuzumab and pertuzumab. (A) A favored theory by assuming the distinctive action of trastuzumab and pertuzumab on HER2 homo- and heterodimers with or without ligand. (B) Hypothesis based on computational analysis, which suggests cooperative interactions between the two antibodies.

However, several issues need to be resolved to sustain this theory. First, what is the structure basis for pertuzumab to only inhibit HER2 heterodimerization but not HER2 homodimerization? There is no data to indicate that HER2 homodimerization is not mediated by the dimerization domain. Conversely, a recent study with crystallized HER2 ECD homodimer indicates that HER2 homodimer is formed through the interaction of domain II in one protomer with the C-shaped pocket created by domain I-III of the adjacent HER2 protomer [189]. The same research further showed that pertuzumab, but not trastuzumab, blocks the homodimerization of HER2 [189]. In our recent study with Chinese hamster ovary (CHO) cells stably expressing only HER2 (no other HER receptors), HER2 massively forms homodimers due to overexpression. However, trastuzumab does not inhibit the formation of HER2 homodimers [104]. In addition, trastuzumab does not block the phosphorylation of any of the major C-terminal tyrosine residues. However, trastuzumab stimulates strong ADCC in the cells [104]. Thus, it is likely that pertuzumab, rather than trastuzumab, also inhibits the homodimerization of HER2. Secondly, the findings by Junttila et al. [187] suggest that the ligand-independent HER2/HER3 
complex in trastuzumab-sensitive cells is structurally distinct form heregulin-induced HER2/HER3 heterodimers. However, until now no further research to compare the structure of ligand-independent HER2/HER3 heterodimer with the structure of heregulin-induced HER2/HER3 heterodimers has been undertaken.

Despite the problems with the favored theory discussed above, the concept that the synergy is due to the different functions of these two antibodies in targeting HER2-positive cancer cells could still prevail, as increasing amounts of data point to the different functions of these two antibodies in targeting HER2-positive cancer cells. It is likely that pertuzumab acts to disrupt the canonical cell-signaling cascades mediated by activated HER2, especially the signaling pathways activated by heregulin-induced heterodimerization of HER2/HER3. Indeed, so far, no data disputes the role of pertuzumab in inhibiting the formation of HER2 heterodimer and blocking the intracellular signaling downstream of HER2 heterodimers. Instead, more data support the role of pertuzumab in disrupting heregulin-induced HER2/HER3 heterodimers, and the activation of the PI3K/Akt pathway downstream of HER2/HER3 heterodimers [174,186,188]. On the other hand, the action of trastuzumab may come through non-canonical pathways downstream of HER2. Trastuzumab has consistently been shown to elicit strong ADCC [96-104]. Trastuzumab is reported to block HER2 endocytosis/downregulation [120-123], DNA repair [137], proteolytic cleavage of HER2 extracellular domain [126], and angiogenesis [139,140]. It was recently reported that trastuzumab, but not pertuzumab, inhibits autophagy and increases the production of reactive oxygen species in human cardiomyocytes by dysregulating HER2 signaling [190].

The second hypothesis is through computational analysis. This analysis is based on several previous publications [171,180,186,187] that formed bases of Hypothesis 1 [183]. The computational model revealed that trastuzumab and pertuzumab alone or in combination differentially suppress HER receptor-mediated cell signaling. This suppression is dependent on the expression pattern of various HER receptors. Trastuzumab treatment upregulates HER3, which reprograms HER receptor kinetics from HER2 homodimerization to HER2/HER3 heterodimerization. As trastuzumab is more effective in targeting HER2 homodimers and pertuzumab is more effective in targeting HER2/HER3 heterodimers, the synergy is due to the effectiveness of the combination of the two antibodies on targeting both HER2 and HER2/HER3 heterodimers [183]. This hypothesis could be considered to be the extension of Hypothesis 1.

The third hypothesis is also based on a molecular modeling study. This hypothesis suggests that the synergy of trastuzumab and pertuzumab is partly due to the enhanced affinity that originates from the cooperative interactions between the two antibodies (Figure 3B). This model assumes that the two antibodies can colocalize on the extracellular domain of the same HER2 molecule [184]. Following the binding of trastuzumab, the receptor becomes highly plastic, especially on domains I and III, which promotes the association of pertuzumab with HER2. On the other hand, the binding of pertuzumab to HER2 induces novel interactions between HER2 and trastuzumab. The enhanced binding of both antibodies to HER2 inhibits HER2 dimerization and possibly higher oligomerizations with other HER receptor molecules [184]. Since this, it has been reported that the binding of radio-labeled trastuzumab and pertuzumab to HER2-positive cells is increased when both antibodies are applied together compared to when they are applied separately [191]. However, this mechanism was later disputed by another study with experimental characterization by measuring the binding kinetics of trastuzumab and pertuzumab, either the whole antibodies or the F(ab)s, to HER2 extracellular domains [126]. This later research indicates that both pertuzumab and trastuzumab do colocalize on to the same HER2 molecule, but do not augment the binding of each other [192].

\section{Other Anti-HER2 Strategies beyond Pertuzumab}

In addition to trastuzumab and pertuzumab discussed above, many other agents and strategies have also been developed to target HER2. We have discussed the combination of targeting HER2 and PI3K-Akt-mTor above. The other agents and strategies developed simultaneously include the 
anti-HER2 agents that target the signaling pathways downstream of HER2 include the tyrosine kinase inhibitors (TKIs) such as neratinib and lapatinib, and the antibody-drug conjugate trastuzumab emtansine (T-DM1) $[23,176,193,194]$. The recent trends and development in this field include the immunotherapy agents such as anti-PD-L1 agent pembrolizumab [195], the bispecific antibodies such as MCLA-128, which targets both HER2 and HER3 [196], and ZW25, which targets different epitopes on the HER2 extracellular domain, the antibody-drug conjugates (ADCs) such as SYD-0985 and DS-8201a, and new anti-HER2 antibodies and pan-HER TKIs [177]. These new agents and novel strategies have resulted in a multitude of opportunities to capitalize on the biology of HER2-positive breast cancer and ultimately improve responses to HER2-targeted therapy.

\section{Conclusions}

The approval of trastuzumab in treating breast cancer changes the paradigm of breast cancer treatment. To increase the effectiveness and overcome the resistance, pertuzumab was later introduced to treat breast cancer patients together with trastuzumab and docetaxel. While a better outcome is achieved by the combination of pertuzumab, trastuzumab and docetaxel, the percentage of HER2-positive breast cancer patients who benefited from the treatment is still low. Understanding the mechanisms of the action and synergy of trastuzumab and pertuzumab is essential to develop novel therapies for increased effectiveness. While more research is needed to resolve the controversy and elucidate the detail of the mechanism, accumulated data have suggested a likely model for the synergy of trastuzumab and pertuzumab. In this model, the synergy is mostly due to the distinctive mode of action of these two antibodies (Figure 4). Pertuzumab may mostly act to inhibit the classical signaling pathways stimulated by active HER2, including receptor dimerization, receptor phosphorylation and the activation of signaling proteins downstream from HER receptors, including Erk and Akt. Furthermore, trastuzumab may mostly act through pathways other than the classical HER2-signaling cascades. Trastuzumab stimulates strong ADCC, and blocks the generation of active p95HER2 fragments by inhibiting the cleavage of HER2, and others. Certainly, further research is needed to completely elucidate the molecular mechanisms underlying the action and synergy of trastuzumab and pertuzumab.

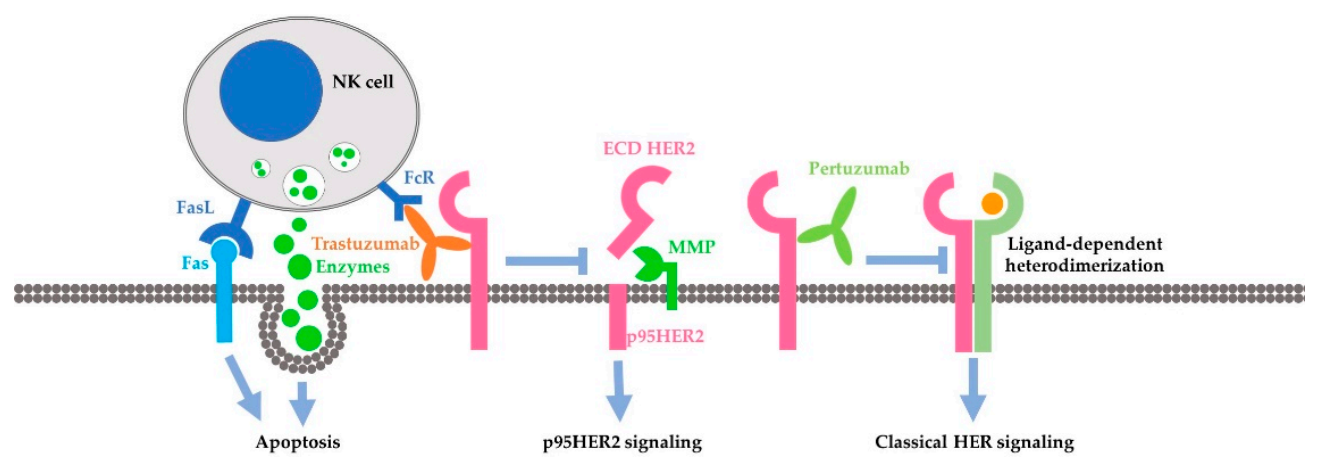

Figure 4. Model proposed in this review by including more recent data. Pertuzumab acts to inhibit the classical HER2-mediated cell-signaling cascades by blocking HER2 dimerization. Trastuzumab acts through ADCC and the inhibition of HER2 cleavage.

Author Contributions: B.N., H.M. and Z.W. all participated in the writing of the manuscript.

Funding: This research was funded in part by grants from Canadian Institutes of Health Research (CIHR) to ZW. BN received a Graduate Studentship from Women and Children's Health Research Institute (WCHRI). No specific funding was received for this study.

Conflicts of Interest: The authors declare no conflict of interest. 


\section{References}

1. Yarden, Y.; Sliwkowski, M.X. Untangling the ErbB signalling network. Nat. Rev. Mol. Cell Biol. 2001, 2, 127-137. [CrossRef] [PubMed]

2. Citri, A.; Yarden, Y. Egf-ErbB signalling: Towards the systems level. Nat. Rev. Mol. Cell Biol. 2006, 7, 505-516. [CrossRef] [PubMed]

3. Peles, E.; Yarden, Y. Neu and its ligands: From an oncogene to neural factors. BioEssays News Rev. Mol. Cell. Dev. Biol. 1993, 15, 815-824. [CrossRef] [PubMed]

4. Rajkumar, T.; Gullick, W.J. The type I growth factor receptors in human breast cancer. Breast Cancer Res. Treat. 1994, 29, 3-9. [CrossRef] [PubMed]

5. Hynes, N.E.; MacDonald, G. ErbB receptors and signaling pathways in cancer. Curr. Opin. Cell Biol. 2009, 21, 177-184. [CrossRef] [PubMed]

6. Spector, N.L.; Blackwell, K.L. Understanding the mechanisms behind trastuzumab therapy for human epidermal growth factor receptor 2-positive breast cancer. J. Clin. Oncol. 2009, 27, 5838-5847. [CrossRef] [PubMed]

7. Cai, Z.; Zhang, H.; Liu, J.; Berezov, A.; Murali, R.; Wang, Q.; Greene, M.I. Targeting ErbB receptors. Semin. Cell Dev. Biol. 2010, 21, 961-966. [CrossRef] [PubMed]

8. Fiszman, G.L.; Jasnis, M.A. Molecular mechanisms of trastuzumab resistance in HER2 overexpressing breast cancer. Int. J. Breast Cancer 2011, 2011, 352182. [CrossRef] [PubMed]

9. Mahipal, A.; Kothari, N.; Gupta, S. Epidermal growth factor receptor inhibitors: Coming of age. Cancer Control J. Moffitt Cancer Cent. 2014, 21, 74-79. [CrossRef] [PubMed]

10. Lluch, A.; Eroles, P.; Perez-Fidalgo, J.A. Emerging EGFR antagonists for breast cancer. Expert Opin. Emerg. Drugs 2014, 19, 165-181. [CrossRef] [PubMed]

11. Rimawi, M.F.; Schiff, R.; Osborne, C.K. Targeting HER2 for the treatment of breast cancer. Ann. Rev. Med. 2015, 66, 111-128. [CrossRef] [PubMed]

12. Wang, Z. ErbB receptors and cancer. Methods Mol. Biol. 2017, 1652, 3-35. [PubMed]

13. Slamon, D.J.; Clark, G.M.; Wong, S.G.; Levin, W.J.; Ullrich, A.; McGuire, W.L. Human breast cancer: Correlation of relapse and survival with amplification of the HER-2/neu oncogene. Science 1987, 235, 177-182. [CrossRef] [PubMed]

14. Slamon, D.J.; Godolphin, W.; Jones, L.A.; Holt, J.A.; Wong, S.G.; Keith, D.E.; Levin, W.J.; Stuart, S.G.; Udove, J.; Ullrich, A. Studies of the her-2/neu proto-oncogene in human breast and ovarian cancer. Science 1989, 244, 707-712. [CrossRef] [PubMed]

15. Gullick, W.J. The c-ErbB3/HER3 receptor in human cancer. Cancer Surv. 1996, 27, 339-349. [PubMed]

16. Hynes, N.E.; Lane, H.A. ErbB receptors and cancer: The complexity of targeted inhibitors. Nat. Rev. Cancer 2005, 5, 341-354. [CrossRef] [PubMed]

17. Capdevila, J.; Elez, E.; Macarulla, T.; Ramos, F.J.; Ruiz-Echarri, M.; Tabernero, J. Anti-epidermal growth factor receptor monoclonal antibodies in cancer treatment. Cancer Treat. Rev. 2009, 35, 354-363. [CrossRef] [PubMed]

18. Ross, J.S.; Slodkowska, E.A.; Symmans, W.F.; Pusztai, L.; Ravdin, P.M.; Hortobagyi, G.N. The HER-2 receptor and breast cancer: Ten years of targeted anti-HER-2 therapy and personalized medicine. Oncologist 2009, 14, 320-368. [CrossRef] [PubMed]

19. De Mattos-Arruda, L.; Cortes, J. Use of pertuzumab for the treatment of HER2-positive metastatic breast cancer. Adv. Ther. 2013, 30, 645-658. [CrossRef] [PubMed]

20. Dawood, S.; Broglio, K.; Buzdar, A.U.; Hortobagyi, G.N.; Giordano, S.H. Prognosis of women with metastatic breast cancer by HER2 status and trastuzumab treatment: An institutional-based review. J. Clin. Oncol. 2010, 28, 92-98. [CrossRef] [PubMed]

21. Nahta, R.; Yu, D.; Hung, M.C.; Hortobagyi, G.N.; Esteva, F.J. Mechanisms of disease: Understanding resistance to HER2-targeted therapy in human breast cancer. Nat. Clin. Pract. Oncol. 2006, 3, 269-280. [CrossRef] [PubMed]

22. Arteaga, C.L.; Sliwkowski, M.X.; Osborne, C.K.; Perez, E.A.; Puglisi, F.; Gianni, L. Treatment of HER2-positive breast cancer: Current status and future perspectives. Nat. Rev. Clin. Oncol. 2012, 9, 16-32. [CrossRef] [PubMed] 
23. Baselga, J.; Cortes, J.; Kim, S.B.; Im, S.A.; Hegg, R.; Im, Y.H.; Roman, L.; Pedrini, J.L.; Pienkowski, T.; Knott, A.; et al. Pertuzumab plus trastuzumab plus docetaxel for metastatic breast cancer. N. Engl. J. Med. 2012, 366, 109-119. [CrossRef] [PubMed]

24. Gu, G.; Dustin, D.; Fuqua, S.A. Targeted therapy for breast cancer and molecular mechanisms of resistance to treatment. Curr. Opin. Pharmacol. 2016, 31, 97-103. [CrossRef] [PubMed]

25. Gleeson, J.P.; Keegan, N.M.; Morris, P.G. Adding pertuzumab to trastuzumab and taxanes in HER2 positive breast cancer. Expert Opin. Biol. Ther. 2018, 18, 251-262. [CrossRef] [PubMed]

26. von Minckwitz, G.; Procter, M.; de Azambuja, E.; Zardavas, D.; Benyunes, M.; Viale, G.; Suter, T.; Arahmani, A.; Rouchet, N.; Clark, E.; et al. Adjuvant pertuzumab and trastuzumab in early HER2-positive breast cancer. N. Engl. J. Med. 2017, 377, 122-131. [CrossRef] [PubMed]

27. Loibl, S.; Gianni, L. HER2-positive breast cancer. Lancet 2017, 389, 2415-2429. [CrossRef]

28. Perou, C.M.; Sorlie, T.; Eisen, M.B.; van de Rijn, M.; Jeffrey, S.S.; Rees, C.A.; Pollack, J.R.; Ross, D.T.; Johnsen, H.; Akslen, L.A.; et al. Molecular portraits of human breast tumours. Nature 2000, 406, 747-752. [CrossRef] [PubMed]

29. Yardley, D.A. Drug resistance and the role of combination chemotherapy in improving patient outcomes. Int. J. Breast Cancer 2013, 2013, 137414. [CrossRef] [PubMed]

30. Roskoski, R., Jr. The ErbB/her family of protein-tyrosine kinases and cancer. Pharmacol. Res. 2014, 79, 34-74. [CrossRef] [PubMed]

31. Arteaga, C.L.; Engelman, J.A. ErbB receptors: From oncogene discovery to basic science to mechanism-based cancer therapeutics. Cancer Cell 2014, 25, 282-303. [CrossRef] [PubMed]

32. Hsu, J.L.; Hung, M.C. The role of HER2, EGFR, and other receptor tyrosine kinases in breast cancer. Cancer Metastasis Rev. 2016, 35, 575-588. [CrossRef] [PubMed]

33. Lehmann, B.D.; Bauer, J.A.; Chen, X.; Sanders, M.E.; Chakravarthy, A.B.; Shyr, Y.; Pietenpol, J.A. Identification of human triple-negative breast cancer subtypes and preclinical models for selection of targeted therapies. J. Clin. Investig. 2011, 121, 2750-2767. [CrossRef] [PubMed]

34. Masuda, H.; Zhang, D.; Bartholomeusz, C.; Doihara, H.; Hortobagyi, G.N.; Ueno, N.T. Role of epidermal growth factor receptor in breast cancer. Breast Cancer Res. Treat. 2012, 136, 331-345. [CrossRef] [PubMed]

35. Reese, D.M.; Slamon, D.J. HER-2/NEU signal transduction in human breast and ovarian cancer. Stem. Cells 1997, 15, 1-8. [CrossRef] [PubMed]

36. Bose, R.; Kavuri, S.M.; Searleman, A.C.; Shen, W.; Shen, D.; Koboldt, D.C.; Monsey, J.; Goel, N.; Aronson, A.B.; $\mathrm{Li}$, S.; et al. Activating HER2 mutations in HER2 gene amplification negative breast cancer. Cancer Discov. 2013, 3, 224-237. [CrossRef] [PubMed]

37. Natali, P.G.; Nicotra, M.R.; Bigotti, A.; Venturo, I.; Slamon, D.J.; Fendly, B.M.; Ullrich, A. Expression of the p185 encoded by HER2 oncogene in normal and transformed human tissues. Int. J. Cancer 1990, 45, 457-461. [CrossRef] [PubMed]

38. Lacroix, H.; Iglehart, J.D.; Skinner, M.A.; Kraus, M.H. Overexpression of ErbB-2 or EGF receptor proteins present in early stage mammary carcinoma is detected simultaneously in matched primary tumors and regional metastases. Oncogene 1989, 4, 145-151. [PubMed]

39. Tan, M.; Yao, J.; Yu, D. Overexpression of the c-ErbB-2 gene enhanced intrinsic metastasis potential in human breast cancer cells without increasing their transformation abilities. Cancer Res. 1997, 57, 1199-1205. [PubMed]

40. Hudziak, R.M.; Schlessinger, J.; Ullrich, A. Increased expression of the putative growth factor receptor p185HER2 causes transformation and tumorigenesis of NIH 3T3 cells. Proc. Natl. Acad. Sci. USA 1987, 84, 7159-7163. [CrossRef] [PubMed]

41. Di Fiore, P.P.; Pierce, J.H.; Kraus, M.H.; Segatto, O.; King, C.R.; Aaronson, S.A. ErbB-2 is a potent oncogene when overexpressed in NIH/3T3 cells. Science 1987, 237, 178-182. [CrossRef] [PubMed]

42. Pietras, R.J.; Arboleda, J.; Reese, D.M.; Wongvipat, N.; Pegram, M.D.; Ramos, L.; Gorman, C.M.; Parker, M.G.; Sliwkowski, M.X.; Slamon, D.J. HER-2 tyrosine kinase pathway targets estrogen receptor and promotes hormone-independent growth in human breast cancer cells. Oncogene 1995, 10, 2435-2446. [PubMed]

43. Burgess, A.W. EGFR family: Structure physiology signalling and therapeutic targets. Growth Factors 2008, 26, 263-274. [CrossRef] [PubMed]

44. Skinner, A.; Hurst, H.C. Transcriptional regulation of the c-ErbB-3 gene in human breast carcinoma cell lines. Oncogene 1993, 8, 3393-3401. [PubMed] 
45. Jaiswal, B.S.; Kljavin, N.M.; Stawiski, E.W.; Chan, E.; Parikh, C.; Durinck, S.; Chaudhuri, S.; Pujara, K.; Guillory, J.; Edgar, K.A.; et al. Oncogenic ErbB3 mutations in human cancers. Cancer Cell 2013, 23, 603-617. [CrossRef] [PubMed]

46. Carpenter, G. ErbB-4: Mechanism of action and biology. Exp. Cell Res. 2003, 284, 66-77. [CrossRef]

47. Jones, F.E. HER4 intracellular domain (4ICD) activity in the developing mammary gland and breast cancer. J. Mammary Gland Biol. Neoplasia 2008, 13, 247-258. [CrossRef] [PubMed]

48. Hollmen, M.; Elenius, K. Potential of ErbB4 antibodies for cancer therapy. Future Oncol. 2010, 6, 37-53. [CrossRef] [PubMed]

49. Veikkolainen, V.; Vaparanta, K.; Halkilahti, K.; Iljin, K.; Sundvall, M.; Elenius, K. Function of ErbB4 is determined by alternative splicing. Cell Cycle 2011, 10, 2647-2657. [CrossRef] [PubMed]

50. Lemmon, M.A.; Schlessinger, J. Cell signaling by receptor tyrosine kinases. Cell 2010, 141, 1117-1134. [CrossRef] [PubMed]

51. Kovacs, E.; Zorn, J.A.; Huang, Y.; Barros, T.; Kuriyan, J. A structural perspective on the regulation of the epidermal growth factor receptor. Ann. Rev. Biochem. 2015, 84, 739-764. [CrossRef] [PubMed]

52. Ward, C.W.; Hoyne, P.A.; Flegg, R.H. Insulin and epidermal growth factor receptors contain the cysteine repeat motif found in the tumor necrosis factor receptor. Proteins 1995, 22, 141-153. [CrossRef] [PubMed]

53. Carpenter, G.; Lembach, K.J.; Morrison, M.M.; Cohen, S. Characterization of the binding of 125-I-labeled epidermal growth factor to human fibroblasts. J. Biol. Chem. 1975, 250, 4297-4304. [PubMed]

54. Ullrich, A.; Coussens, L.; Hayflick, J.S.; Dull, T.J.; Gray, A.; Tam, A.W.; Lee, J.; Yarden, Y.; Libermann, T.A.; Schlessinger, J. Human epidermal growth factor receptor cdna sequence and aberrant expression of the amplified gene in a431 epidermoid carcinoma cells. Nature 1984, 309, 418-425. [CrossRef] [PubMed]

55. Velu, T.J.; Beguinot, L.; Vass, W.C.; Willingham, M.C.; Merlino, G.T.; Pastan, I.; Lowy, D.R. Epidermal-growth-factor-dependent transformation by a human egf receptor proto-oncogene. Science 1987, 238, 1408-1410. [CrossRef] [PubMed]

56. Kim, Y.T.; Park, S.W.; Kim, J.W. Correlation between expression of EGFR and the prognosis of patients with cervical carcinoma. Gynecol. Oncol. 2002, 87, 84-89. [CrossRef] [PubMed]

57. Kopp, R.; Rothbauer, E.; Ruge, M.; Arnholdt, H.; Spranger, J.; Muders, M.; Pfeiffer, D.G.; Schildberg, F.W.; Pfeiffer, A. Clinical implications of the EGF receptor/ligand system for tumor progression and survival in gastrointestinal carcinomas: Evidence for new therapeutic options. Recent Results Cancer Res. 2003, 162, 115-132. [PubMed]

58. Nicholson, R.I.; Gee, J.M.; Harper, M.E. EGFR and cancer prognosis. Eur. J. Cancer 2001, 37 (Suppl. 4), S9-S15. [CrossRef]

59. Carraway, K.L., 3rd; Cantley, L.C. A neu acquaintance for ErbB3 and ErbB4: A role for receptor heterodimerization in growth signaling. Cell 1994, 78, 5-8. [CrossRef]

60. Pinkas-Kramarski, R.; Soussan, L.; Waterman, H.; Levkowitz, G.; Alroy, I.; Klapper, L.; Lavi, S.; Seger, R.; Ratzkin, B.J.; Sela, M.; et al. Diversification of NEU differentiation factor and epidermal growth factor signaling by combinatorial receptor interactions. EMBO J. 1996, 15, 2452-2467. [CrossRef] [PubMed]

61. Coussens, L.; Yang-Feng, T.L.; Liao, Y.C.; Chen, E.; Gray, A.; McGrath, J.; Seeburg, P.H.; Libermann, T.A.; Schlessinger, J.; Francke, U. Tyrosine kinase receptor with extensive homology to egf receptor shares chromosomal location with neu oncogene. Science 1985, 230, 1132-1139. [CrossRef] [PubMed]

62. Schlessinger, J.; Ullrich, A. Growth factor signaling by receptor tyrosine kinases. Neuron 1992, 9, $383-391$. [CrossRef]

63. Pawson, T. Protein modules and signalling networks. Nature 1995, 373, 573-580. [CrossRef] [PubMed]

64. Shih, C.; Padhy, L.C.; Murray, M.; Weinberg, R.A. Transforming genes of carcinomas and neuroblastomas introduced into mouse fibroblasts. Nature 1981, 290, 261-264. [CrossRef] [PubMed]

65. Bargmann, C.I.; Hung, M.C.; Weinberg, R.A. Multiple independent activations of the neu oncogene by a point mutation altering the transmembrane domain of p185. Cell 1986, 45, 649-657. [CrossRef]

66. Yonemura, Y.; Ninomiya, I.; Ohoyama, S.; Kimura, H.; Yamaguchi, A.; Fushida, S.; Kosaka, T.; Miwa, K.; Miyazaki, I.; Endou, Y.; et al. Expression of c-ErbB-2 oncoprotein in gastric carcinoma. Immunoreactivity for c-ErbB-2 protein is an independent indicator of poor short-term prognosis in patients with gastric carcinoma. Cancer 1991, 67, 2914-2918. [CrossRef] 
67. Press, M.F.; Pike, M.C.; Hung, G.; Zhou, J.Y.; Ma, Y.; George, J.; Dietz-Band, J.; James, W.; Slamon, D.J.; Batsakis, J.G.; et al. Amplification and overexpression of HER-2/NEU in carcinomas of the salivary gland: Correlation with poor prognosis. Cancer Res. 1994, 54, 5675-5682. [PubMed]

68. Kraus, M.H.; Issing, W.; Miki, T.; Popescu, N.C.; Aaronson, S.A. Isolation and characterization of ErbB3, a third member of the ErbB/epidermal growth factor receptor family: Evidence for overexpression in a subset of human mammary tumors. Proc. Natl. Acad. Sci. USA 1989, 86, 9193-9197. [CrossRef] [PubMed]

69. Cacace, A.M.; Guadagno, S.N.; Krauss, R.S.; Fabbro, D.; Weinstein, I.B. The epsilon isoform of protein kinase $\mathrm{C}$ is an oncogene when overexpressed in rat fibroblasts. Oncogene 1993, 8, 2095-2104. [PubMed]

70. Rajkumar, T.; Majhi, U.; Malligarjuna, V.; Gullick, W. Prevalence of c-ErbB3 expression in squamous-cell carcinomas of the cervix as determined by the monoclonal-antibody RTJ2. Int. J. Oncol. 1995, 6, 105-109. [CrossRef] [PubMed]

71. Prigent, S.A.; Gullick, W.J. Identification of c-ErbB-3 binding sites for phophatidylinositol 3'-kinase and SHC using an EGF receptor/c-ErbB-3 chimera. EMBO J. 1994, 13, 2831-2841. [CrossRef] [PubMed]

72. Shi, F.; Telesco, S.E.; Liu, Y.; Radhakrishnan, R.; Lemmon, M.A. ErbB3/HER3 intracellular domain is competent to bind ATP and catalyze autophosphorylation. Proc. Natl. Acad. Sci. USA 2010, 107, 7692-7697. [CrossRef] [PubMed]

73. Sardi, S.P.; Murtie, J.; Koirala, S.; Patten, B.A.; Corfas, G. Presenilin-dependent ErbB4 nuclear signaling regulates the timing of astrogenesis in the developing brain. Cell 2006, 127, 185-197. [CrossRef] [PubMed]

74. Kinugasa, Y.; Ishiguro, H.; Tokita, Y.; Oohira, A.; Ohmoto, H.; Higashiyama, S. Neuroglycan C, a novel member of the neuregulin family. Biochem. Biophys. Res. Commun. 2004, 321, 1045-1049. [CrossRef] [PubMed]

75. Kochupurakkal, B.S.; Harari, D.; Di-Segni, A.; Maik-Rachline, G.; Lyass, L.; Gur, G.; Kerber, G.; Citri, A.; Lavi, S.; Eilam, R.; et al. Epigen, the last ligand of ErbB receptors, reveals intricate relationships between affinity and mitogenicity. J. Biol. Chem. 2005, 280, 8503-8512. [CrossRef] [PubMed]

76. Normanno, N.; Bianco, C.; Strizzi, L.; Mancino, M.; Maiello, M.R.; De Luca, A.; Caponigro, F.; Salomon, D.S. The ErbB receptors and their ligands in cancer: An overview. Curr. Drug Targets 2005, 6, 243-257. [CrossRef] [PubMed]

77. Franklin, M.C.; Carey, K.D.; Vajdos, F.F.; Leahy, D.J.; de Vos, A.M.; Sliwkowski, M.X. Insights into ErbB signaling from the structure of the ErbB2-pertuzumab complex. Cancer Cell 2004, 5, 317-328. [CrossRef]

78. Lemmon, M.A. Ligand-induced ErbB receptor dimerization. Exp. Cell Res. 2009, 315, 638-648. [CrossRef] [PubMed]

79. Ferguson, K.M. Structure-based view of epidermal growth factor receptor regulation. Ann. Rev. Biophys. 2008, 37, 353-373. [CrossRef] [PubMed]

80. Rotin, D.; Honegger, A.M.; Margolis, B.L.; Ullrich, A.; Schlessinger, J. Presence of SH2 domains of phospholipase $\mathrm{C}$ gamma 1 enhances substrate phosphorylation by increasing the affinity toward the epidermal growth factor receptor. J. Biol. Chem. 1992, 267, 9678-9683. [PubMed]

81. Cohen, B.D.; Kiener, P.A.; Green, J.M.; Foy, L.; Fell, H.P.; Zhang, K. The relationship between human epidermal growth-like factor receptor expression and cellular transformation in NIH3T3 cells. J. Biol. Chem. 1996, 271, 30897-30903. [CrossRef] [PubMed]

82. Zrihan-Licht, S.; Deng, B.; Yarden, Y.; McShan, G.; Keydar, I.; Avraham, H. CSK homologous kinase, a novel signaling molecule, directly associates with the activated ErbB-2 receptor in breast cancer cells and inhibits their proliferation. J. Biol. Chem. 1998, 273, 4065-4072. [CrossRef] [PubMed]

83. Keilhack, H.; Tenev, T.; Nyakatura, E.; Godovac-Zimmermann, J.; Nielsen, L.; Seedorf, K.; Bohmer, F.D. Phosphotyrosine 1173 mediates binding of the protein-tyrosine phosphatase SHP-1 to the epidermal growth factor receptor and attenuation of receptor signaling. J. Biol. Chem. 1998, 273, 24839-24846. [CrossRef] [PubMed]

84. Hellyer, N.J.; Kim, M.S.; Koland, J.G. Heregulin-dependent activation of phosphoinositide 3-kinase and Akt via the ErbB2/ErbB3 co-receptor. J. Biol. Chem. 2001, 276, 42153-42161. [CrossRef] [PubMed]

85. Schulze, W.X.; Deng, L.; Mann, M. Phosphotyrosine interactome of the ErbB-receptor kinase family. Mol. Syst. Biol. 2005, 1. [CrossRef] [PubMed]

86. Kaushansky, A.; Gordus, A.; Budnik, B.A.; Lane, W.S.; Rush, J.; MacBeath, G. System-wide investigation of ErbB4 reveals 19 sites of Tyr phosphorylation that are unusually selective in their recruitment properties. Chem. Biol. 2008, 15, 808-817. [CrossRef] [PubMed] 
87. Wilson, K.J.; Gilmore, J.L.; Foley, J.; Lemmon, M.A.; Riese, D.J., 2nd. Functional selectivity of EGF family peptide growth factors: Implications for cancer. Pharmacol. Ther. 2009, 122, 1-8. [CrossRef] [PubMed]

88. Sato, K. Cellular functions regulated by phosphorylation of EGFR on TYR845. Int. J. Mol. Sci. 2013, 14, 10761-10790. [CrossRef] [PubMed]

89. Downward, J. Ras signalling and apoptosis. Curr. Opin. Genet. Dev. 1998, 8, 49-54. [CrossRef]

90. Castellano, E.; Downward, J. Ras interaction with PI3K: More than just another effector pathway. Genes Cancer 2011, 2, 261-274. [CrossRef] [PubMed]

91. Burgering, B.M.; Coffer, P.J. Protein kinase b (c-Akt) in phosphatidylinositol-3-OH kinase signal transduction. Nature 1995, 376, 599-602. [CrossRef] [PubMed]

92. Downward, J. Mechanisms and consequences of activation of protein kinase B/Akt. Curr. Opin. Cell Biol. 1998, 10, 262-267. [CrossRef]

93. Okano, J.; Gaslightwala, I.; Birnbaum, M.J.; Rustgi, A.K.; Nakagawa, H. Akt/protein kinase B isoforms are differentially regulated by epidermal growth factor stimulation. J. Biol. Chem. 2000, 275, 30934-30942. [CrossRef] [PubMed]

94. Skeen, J.E.; Bhaskar, P.T.; Chen, C.-C.; Chen, W.S.; Peng, X.-D.; Nogueira, V.; Hahn-Windgassen, A.; Kiyokawa, H.; Hay, N. Akt deficiency impairs normal cell proliferation and suppresses oncogenesis in a p53-independent and mTORC1-dependent manner. Cancer Cell. 2006, 10, 269-280. [CrossRef] [PubMed]

95. Nuti, M.; Bellati, F.; Visconti, V.; Napoletano, C.; Domenici, L.; Caccetta, J.; Zizzari, I.G.; Ruscito, I.; Rahimi, H.; Benedetti-Panici, P.; et al. Immune effects of trastuzumab. J. Cancer 2011, 2, 317-323. [CrossRef] [PubMed]

96. Clynes, R.A.; Towers, T.L.; Presta, L.G.; Ravetch, J.V. Inhibitory FC receptors modulate in vivo cytotoxicity against tumor targets. Nat. Med. 2000, 6, 443-446. [CrossRef] [PubMed]

97. Arnould, L.; Gelly, M.; Penault-Llorca, F.; Benoit, L.; Bonnetain, F.; Migeon, C.; Cabaret, V.; Fermeaux, V.; Bertheau, P.; Garnier, J.; et al. Trastuzumab-based treatment of HER2-positive breast cancer: An antibody-dependent cellular cytotoxicity mechanism? Br. J. Cancer 2006, 94, 259-267. [CrossRef] [PubMed]

98. Varchetta, S.; Gibelli, N.; Oliviero, B.; Nardini, E.; Gennari, R.; Gatti, G.; Silva, L.S.; Villani, L.; Tagliabue, E.; Menard, S.; et al. Elements related to heterogeneity of antibody-dependent cell cytotoxicity in patients under trastuzumab therapy for primary operable breast cancer overexpressing HER2. Cancer Res. 2007, 67, 11991-11999. [CrossRef] [PubMed]

99. Kute, T.; Stehle, J.R., Jr.; Ornelles, D.; Walker, N.; Delbono, O.; Vaughn, J.P. Understanding key assay parameters that affect measurements of trastuzumab-mediated ADCC against HER2 positive breast cancer cells. Oncoimmunology 2012, 1, 810-821. [CrossRef] [PubMed]

100. Petricevic, B.; Laengle, J.; Singer, J.; Sachet, M.; Fazekas, J.; Steger, G.; Bartsch, R.; Jensen-Jarolim, E.; Bergmann, M. Trastuzumab mediates antibody-dependent cell-mediated cytotoxicity and phagocytosis to the same extent in both adjuvant and metastatic HER2/NEU breast cancer patients. J. Transl. Med. 2013, 11, 307. [CrossRef] [PubMed]

101. Duong, M.N.; Cleret, A.; Matera, E.L.; Chettab, K.; Mathe, D.; Valsesia-Wittmann, S.; Clemenceau, B.; Dumontet, C. Adipose cells promote resistance of breast cancer cells to trastuzumab-mediated antibody-dependent cellular cytotoxicity. Breast Cancer Res. 2015, 17, 57. [CrossRef] [PubMed]

102. Shi, Y.; Fan, X.; Deng, H.; Brezski, R.J.; Rycyzyn, M.; Jordan, R.E.; Strohl, W.R.; Zou, Q.; Zhang, N.; An, Z. Trastuzumab triggers phagocytic killing of high HER2 cancer cells in vitro and in vivo by interaction with fcgamma receptors on macrophages. J. Immunol. 2015, 194, 4379-4386. [CrossRef] [PubMed]

103. Scaltriti, M.; Verma, C.; Guzman, M.; Jimenez, J.; Parra, J.L.; Pedersen, K.; Smith, D.J.; Landolfi, S.; Ramon y Cajal, S.; Arribas, J.; et al. Lapatinib, a HER2 tyrosine kinase inhibitor, induces stabilization and accumulation of HER2 and potentiates trastuzumab-dependent cell cytotoxicity. Oncogene 2009, 28, 803-814. [CrossRef] [PubMed]

104. Maadi, H.; Nami, B.; Tong, J.; Li, G.; Wang, Z. The effects of trastuzumab on HER2-mediated cell signaling in cho cells expressing human HER2. BMC Cancer 2018, 18, 238. [CrossRef] [PubMed]

105. Jochems, C.; Hodge, J.W.; Fantini, M.; Fujii, R.; Morillon, Y.M., 2nd; Greiner, J.W.; Padget, M.R.; Tritsch, S.R.; Tsang, K.Y.; Campbell, K.S.; et al. An NK cell line (haNK) expressing high levels of granzyme and engineered to express the high affinity CD16 allele. Oncotarget 2016, 7, 86359-86373. [CrossRef] [PubMed]

106. Sanchez-Martinez, D.; Allende-Vega, N.; Orecchioni, S.; Talarico, G.; Cornillon, A.; Vo, D.N.; Rene, C.; Lu, Z.Y.; Krzywinska, E.; Anel, A.; et al. Expansion of allogeneic nk cells with efficient antibody-dependent cell cytotoxicity against multiple tumors. Theranostics 2018, 8, 3856-3869. [CrossRef] [PubMed] 
107. Bang, Y.J.; Giaccone, G.; Im, S.A.; Oh, D.Y.; Bauer, T.M.; Nordstrom, J.L.; Li, H.; Chichili, G.R.; Moore, P.A.; Hong, S.; et al. First-in-human phase 1 study of margetuximab (MGAH22), an FC-modified chimeric monoclonal antibody, in patients with HER2-positive advanced solid tumors. Ann. Oncol. 2017, 28, 855-861. [CrossRef] [PubMed]

108. Jo, M.; Kwon, H.S.; Lee, K.H.; Lee, J.C.; Jung, S.T. Engineered aglycosylated full-length IGG FC variants exhibiting improved FCgammariiia binding and tumor cell clearance. $m A b s \mathbf{2 0 1 8}, 10,278-289$. [CrossRef] [PubMed]

109. Nakajima, T.; Okayama, H.; Ashizawa, M.; Noda, M.; Aoto, K.; Saito, M.; Monma, T.; Ohki, S.; Shibata, M.; Takenoshita, S.; et al. Augmentation of antibody-dependent cellular cytotoxicity with defucosylated monoclonal antibodies in patients with GI-tract cancer. Oncol. Lett. 2018, 15, 2604-2610. [CrossRef] [PubMed]

110. Evans, M.K.; Sauer, S.J.; Nath, S.; Robinson, T.J.; Morse, M.A.; Devi, G.R. X-linked inhibitor of apoptosis protein mediates tumor cell resistance to antibody-dependent cellular cytotoxicity. Cell Death Dis. 2016, 7, e2073. [CrossRef] [PubMed]

111. Xu, F.; Sunderland, A.; Zhou, Y.; Schulick, R.D.; Edil, B.H.; Zhu, Y. Blockade of CD112R and TIGIT signaling sensitizes human natural killer cell functions. Cancer Immunol. Immunother. CII 2017, 66, 1367-1375. [CrossRef] [PubMed]

112. Pham, D.H.; Kim, J.S.; Kim, S.K.; Shin, D.J.; Uong, N.T.; Hyun, H.; Yoon, M.S.; Kang, S.J.; Ryu, Y.J.; Cho, J.S.; et al. Effects of adam10 and adam17 inhibitors on natural killer cell expansion and antibody-dependent cellular cytotoxicity against breast cancer cells in vitro. Anticancer Res. 2017, 37, 5507-5513. [PubMed]

113. Di Modica, M.; Sfondrini, L.; Regondi, V.; Varchetta, S.; Oliviero, B.; Mariani, G.; Bianchi, G.V.; Generali, D.; Balsari, A.; Triulzi, T.; et al. Taxanes enhance trastuzumab-mediated ADCC on tumor cells through NKG2D-mediated NK cell recognition. Oncotarget 2016, 7, 255-265. [CrossRef] [PubMed]

114. Okita, R.; Shimizu, K.; Nojima, Y.; Yukawa, T.; Maeda, A.; Saisho, S.; Nakata, M. Lapatinib enhances trastuzumab-mediated antibody-dependent cellular cytotoxicity via upregulation of HER2 in malignant mesothelioma cells. Oncol. Rep. 2015, 34, 2864-2870. [CrossRef] [PubMed]

115. Collins, D.M.; Gately, K.; Hughes, C.; Edwards, C.; Davies, A.; Madden, S.F.; O’Byrne, K.J.; O’Donovan, N.; Crown, J. Tyrosine kinase inhibitors as modulators of trastuzumab-mediated antibody-dependent cell-mediated cytotoxicity in breast cancer cell lines. Cell. Immunol. 2017, 319, 35-42. [CrossRef] [PubMed]

116. Gijsen, M.; King, P.; Perera, T.; Parker, P.J.; Harris, A.L.; Larijani, B.; Kong, A. HER2 phosphorylation is maintained by a PKB negative feedback loop in response to anti-HER2 HERceptin in breast cancer. PLoS Biol. 2010, 8, e1000563. [CrossRef] [PubMed]

117. Dokmanovic, M.; Wu, Y.; Shen, Y.; Chen, J.; Hirsch, D.S.; Wu, W.J. Trastuzumab-induced recruitment of CSK-homologous kinase (CHK) to ErbB2 receptor is associated with ErbB2-Y1248 phosphorylation and ErbB2 degradation to mediate cell growth inhibition. Cancer Biol. Ther. 2014, 15, 1029-1041. [CrossRef] [PubMed]

118. Yakes, F.M.; Chinratanalab, W.; Ritter, C.A.; King, W.; Seelig, S.; Arteaga, C.L. Herceptin-induced inhibition of phosphatidylinositol-3 kinase and Akt is required for antibody-mediated effects on p27, cyclin D1, and antitumor action. Cancer Res. 2002, 62, 4132-4141. [PubMed]

119. Xia, W.; Bisi, J.; Strum, J.; Liu, L.; Carrick, K.; Graham, K.M.; Treece, A.L.; Hardwicke, M.A.; Dush, M.; Liao, Q.; et al. Regulation of survivin by ErbB2 signaling: Therapeutic implications for ErbB2-overexpressing breast cancers. Cancer Res. 2006, 66, 1640-1647. [CrossRef] [PubMed]

120. Cuello, M.; Ettenberg, S.A.; Clark, A.S.; Keane, M.M.; Posner, R.H.; Nau, M.M.; Dennis, P.A.; Lipkowitz, S. Down-regulation of the ErbB-2 receptor by trastuzumab (herceptin) enhances tumor necrosis factor-related apoptosis-inducing ligand-mediated apoptosis in breast and ovarian cancer cell lines that overexpress ErbB-2. Cancer Res. 2001, 61, 4892-4900. [PubMed]

121. Austin, C.D.; De Maziere, A.M.; Pisacane, P.I.; van Dijk, S.M.; Eigenbrot, C.; Sliwkowski, M.X.; Klumperman, J.; Scheller, R.H. Endocytosis and sorting of ErbB2 and the site of action of cancer therapeutics trastuzumab and geldanamycin. Mol. Biol. Cell 2004, 15, 5268-5282. [CrossRef] [PubMed]

122. Valabrega, G.; Montemurro, F.; Sarotto, I.; Petrelli, A.; Rubini, P.; Tacchetti, C.; Aglietta, M.; Comoglio, P.M.; Giordano, S. TGFalpha expression impairs trastuzumab-induced HER2 downregulation. Oncogene 2005, 24, 3002-3010. [CrossRef] [PubMed] 
123. Longva, K.E.; Pedersen, N.M.; Haslekas, C.; Stang, E.; Madshus, I.H. Herceptin-induced inhibition of ErbB2 signaling involves reduced phosphorylation of Akt but not endocytic down-regulation of ErbB2. Int. J. Cancer 2005, 116, 359-367. [CrossRef] [PubMed]

124. Merry, C.R.; McMahon, S.; Thompson, C.L.; Miskimen, K.L.; Harris, L.N.; Khalil, A.M. Integrative transcriptome-wide analyses reveal critical HER2-regulated mRNAs and lincRNAs in HER2+ breast cancer. Breast Cancer Res. Treat. 2015, 150, 321-334. [CrossRef] [PubMed]

125. Christianson, T.A.; Doherty, J.K.; Lin, Y.J.; Ramsey, E.E.; Holmes, R.; Keenan, E.J.; Clinton, G.M. NH2-terminally truncated HER-2/NEU protein: Relationship with shedding of the extracellular domain and with prognostic factors in breast cancer. Cancer Res. 1998, 58, 5123-5129. [PubMed]

126. Molina, M.A.; Codony-Servat, J.; Albanell, J.; Rojo, F.; Arribas, J.; Baselga, J. Trastuzumab (herceptin), a humanized anti-HER2 receptor monoclonal antibody, inhibits basal and activated HER2 ectodomain cleavage in breast cancer cells. Cancer Res. 2001, 61, 4744-4749. [PubMed]

127. Scaltriti, M.; Rojo, F.; Ocana, A.; Anido, J.; Guzman, M.; Cortes, J.; Di Cosimo, S.; Matias-Guiu, X.; Ramon y Cajal, S.; Arribas, J.; et al. Expression of p95HER2, a truncated form of the HER2 receptor, and response to anti-HER2 therapies in breast cancer. J. Natl. Cancer Inst. 2007, 99, 628-638. [CrossRef] [PubMed]

128. Sperinde, J.; Jin, X.; Banerjee, J.; Penuel, E.; Saha, A.; Diedrich, G.; Huang, W.; Leitzel, K.; Weidler, J.; Ali, S.M.; et al. Quantitation of p95HER2 in paraffin sections by using a p95-specific antibody and correlation with outcome in a cohort of trastuzumab-treated breast cancer patients. Clin. Cancer Res. 2010, 16, 4226-4235. [CrossRef] [PubMed]

129. Arribas, J.; Esselens, C. Adam17 as a therapeutic target in multiple diseases. Curr. Pharm. Des. 2009, 15, 2319-2335. [CrossRef] [PubMed]

130. Codony-Servat, J.; Albanell, J.; Lopez-Talavera, J.C.; Arribas, J.; Baselga, J. Cleavage of the HER2 ectodomain is a pervanadate-activable process that is inhibited by the tissue inhibitor of metalloproteases- 1 in breast cancer cells. Cancer Res. 1999, 59, 1196-1201. [PubMed]

131. Yuan, C.X.; Lasut, A.L.; Wynn, R.; Neff, N.T.; Hollis, G.F.; Ramaker, M.L.; Rupar, M.J.; Liu, P.; Meade, R. Purification of HER-2 extracellular domain and identification of its cleavage site. Protein Expr. Purif. 2003, 29, 217-222. [CrossRef]

132. Pedersen, K.; Angelini, P.D.; Laos, S.; Bach-Faig, A.; Cunningham, M.P.; Ferrer-Ramon, C.; Luque-Garcia, A.; Garcia-Castillo, J.; Parra-Palau, J.L.; Scaltriti, M.; et al. A naturally occurring HER2 carboxy-terminal fragment promotes mammary tumor growth and metastasis. Mol. Cell. Biol. 2009, 29, 3319-3331. [CrossRef] [PubMed]

133. Anido, J.; Scaltriti, M.; Bech Serra, J.J.; Santiago Josefat, B.; Todo, F.R.; Baselga, J.; Arribas, J. Biosynthesis of tumorigenic HER2 c-terminal fragments by alternative initiation of translation. EMBO J. 2006, 25, 3234-3244. [CrossRef] [PubMed]

134. Molina, M.A.; Saez, R.; Ramsey, E.E.; Garcia-Barchino, M.J.; Rojo, F.; Evans, A.J.; Albanell, J.; Keenan, E.J.; Lluch, A.; Garcia-Conde, J.; et al. NH(2)-terminal truncated HER-2 protein but not full-length receptor is associated with nodal metastasis in human breast cancer. Clin. Cancer Res. 2002, 8, 347-353. [PubMed]

135. Saez, A.; Andreu, F.J.; Segui, M.A.; Bare, M.L.; Fernandez, S.; Dinares, C.; Rey, M. Her-2 gene amplification by chromogenic in situ hybridisation (CISH) compared with fluorescence in situ hybridisation (FISH) in breast cancer-a study of two hundred cases. Breast 2006, 15, 519-527. [CrossRef] [PubMed]

136. Pietras, R.J.; Fendly, B.M.; Chazin, V.R.; Pegram, M.D.; Howell, S.B.; Slamon, D.J. Antibody to HER-2/NEU receptor blocks DNA repair after cisplatin in human breast and ovarian cancer cells. Oncogene 1994, 9, 1829-1838. [PubMed]

137. Pietras, R.J.; Pegram, M.D.; Finn, R.S.; Maneval, D.A.; Slamon, D.J. Remission of human breast cancer xenografts on therapy with humanized monoclonal antibody to HER-2 receptor and DNA-reactive drugs. Oncogene 1998, 17, 2235-2249. [CrossRef] [PubMed]

138. Pietras, R.J.; Poen, J.C.; Gallardo, D.; Wongvipat, P.N.; Lee, H.J.; Slamon, D.J. Monoclonal antibody to HER-2/neureceptor modulates repair of radiation-induced DNA damage and enhances radiosensitivity of human breast cancer cells overexpressing this oncogene. Cancer Res. 1999, 59, 1347-1355. [PubMed]

139. Izumi, Y.; Xu, L.; di Tomaso, E.; Fukumura, D.; Jain, R.K. Tumour biology: Herceptin acts as an anti-angiogenic cocktail. Nature 2002, 416, 279-280. [CrossRef] [PubMed] 
140. Wen, X.F.; Yang, G.; Mao, W.; Thornton, A.; Liu, J.; Bast, R.C., Jr.; Le, X.F. HER2 signaling modulates the equilibrium between pro- and antiangiogenic factors via distinct pathways: Implications for HER2-targeted antibody therapy. Oncogene 2006, 25, 6986-6996. [CrossRef] [PubMed]

141. Rexer, B.N.; Arteaga, C.L. Intrinsic and acquired resistance to HER2-targeted therapies in HER2 gene-amplified breast cancer: Mechanisms and clinical implications. Crit. Rev. Oncog. 2012, 17, 1-16. [CrossRef] [PubMed]

142. Menyhart, O.; Santarpia, L.; Gyorffy, B. A comprehensive outline of trastuzumab resistance biomarkers in HER2 overexpressing breast cancer. Curr. Cancer Drug Targets 2015, 15, 665-683. [CrossRef] [PubMed]

143. Slamon, D.; Pegram, M. Rationale for trastuzumab (Herceptin) in adjuvant breast cancer trials. Semin. Oncol. 2001, 28, 13-19. [CrossRef]

144. Marty, M.; Cognetti, F.; Maraninchi, D.; Snyder, R.; Mauriac, L.; Tubiana-Hulin, M.; Chan, S.; Grimes, D.; Anton, A.; Lluch, A.; et al. Randomized phase ii trial of the efficacy and safety of trastuzumab combined with docetaxel in patients with human epidermal growth factor receptor 2-positive metastatic breast cancer administered as first-line treatment: The m77001 study group. J. Clin. Oncol. 2005, 23, 4265-4274. [CrossRef] [PubMed]

145. Mittendorf, E.A.; Wu, Y.; Scaltriti, M.; Meric-Bernstam, F.; Hunt, K.K.; Dawood, S.; Esteva, F.J.; Buzdar, A.U.; Chen, H.; Eksambi, S.; et al. Loss of HER2 amplification following trastuzumab-based neoadjuvant systemic therapy and survival outcomes. Clin. Cancer Res. 2009, 15, 7381-7388. [CrossRef] [PubMed]

146. Niikura, N.; Liu, J.; Hayashi, N.; Mittendorf, E.A.; Gong, Y.; Palla, S.L.; Tokuda, Y.; Gonzalez-Angulo, A.M.; Hortobagyi, G.N.; Ueno, N.T. Loss of human epidermal growth factor receptor 2 (HER2) expression in metastatic sites of HER2-overexpressing primary breast tumors. J. Clin. Oncol. 2012, 30, 593-599. [CrossRef] [PubMed]

147. Lipton, A.; Goodman, L.; Leitzel, K.; Cook, J.; Sperinde, J.; Haddad, M.; Kostler, W.J.; Huang, W.; Weidler, J.M.; Ali, S.; et al. HER3, p95HER2, and HER2 protein expression levels define multiple subtypes of HER2-positive metastatic breast cancer. Breast Cancer Res. Treat. 2013, 141, 43-53. [CrossRef] [PubMed]

148. Tural, D.; Akar, E.; Mutlu, H.; Kilickap, S. P95 HER2 fragments and breast cancer outcome. Expert Rev. Anticancer Ther. 2014, 14, 1089-1096. [CrossRef] [PubMed]

149. Yonemori, K.; Tsuta, K.; Shimizu, C.; Hatanaka, Y.; Hirakawa, A.; Ono, M.; Kouno, T.; Katsumata, N.; Ando, M.; Tamura, K.; et al. Immunohistochemical expression of HER1, HER3, and HER4 in HER2-positive breast cancer patients treated with trastuzumab-containing neoadjuvant chemotherapy. J. Surg. Oncol. 2010, 101, 222-227. [CrossRef] [PubMed]

150. Gallardo, A.; Lerma, E.; Escuin, D.; Tibau, A.; Munoz, J.; Ojeda, B.; Barnadas, A.; Adrover, E.; Sanchez-Tejada, L.; Giner, D.; et al. Increased signalling of EGFR and IGF1R, and deregulation of PTEN/PI3K/Akt pathway are related with trastuzumab resistance in HER2 breast carcinomas. Br. J. Cancer 2012, 106, 1367-1373. [CrossRef] [PubMed]

151. Zhuang, G.; Brantley-Sieders, D.M.; Vaught, D.; Yu, J.; Xie, L.; Wells, S.; Jackson, D.; Muraoka-Cook, R.; Arteaga, C.; Chen, J. Elevation of receptor tyrosine kinase epha2 mediates resistance to trastuzumab therapy. Cancer Res. 2010, 70, 299-308. [CrossRef] [PubMed]

152. Joshi, J.P.; Brown, N.E.; Griner, S.E.; Nahta, R. Growth differentiation factor 15 (GDF15)-mediated HER2 phosphorylation reduces trastuzumab sensitivity of HER2-overexpressing breast cancer cells. Biochem. Pharmacol. 2011, 82, 1090-1099. [CrossRef] [PubMed]

153. Jensen, J.D.; Knoop, A.; Laenkholm, A.V.; Grauslund, M.; Jensen, M.B.; Santoni-Rugiu, E.; Andersson, M.; Ewertz, M. PIK3CA mutations, PTEN, and pHER2 expression and impact on outcome in HER2-positive early-stage breast cancer patients treated with adjuvant chemotherapy and trastuzumab. Ann. Oncol. 2012, 23, 2034-2042. [CrossRef] [PubMed]

154. Nagata, Y.; Lan, K.H.; Zhou, X.; Tan, M.; Esteva, F.J.; Sahin, A.A.; Klos, K.S.; Li, P.; Monia, B.P.; Nguyen, N.T.; et al. PTEN activation contributes to tumor inhibition by trastuzumab, and loss of PTEN predicts trastuzumab resistance in patients. Cancer Cell 2004, 6, 117-127. [CrossRef] [PubMed]

155. Berns, K.; Horlings, H.M.; Hennessy, B.T.; Madiredjo, M.; Hijmans, E.M.; Beelen, K.; Linn, S.C.; Gonzalez-Angulo, A.M.; Stemke-Hale, K.; Hauptmann, M.; et al. A functional genetic approach identifies the PI3K pathway as a major determinant of trastuzumab resistance in breast cancer. Cancer Cell 2007, 12, 395-402. [CrossRef] [PubMed] 
156. Kataoka, Y.; Mukohara, T.; Shimada, H.; Saijo, N.; Hirai, M.; Minami, H. Association between gain-of-function mutations in PIK3CA and resistance to HER2-targeted agents in HER2-amplified breast cancer cell lines. Ann. Oncol. 2010, 21, 255-262. [CrossRef] [PubMed]

157. Razis, E.; Bobos, M.; Kotoula, V.; Eleftheraki, A.G.; Kalofonos, H.P.; Pavlakis, K.; Papakostas, P.; Aravantinos, G.; Rigakos, G.; Efstratiou, I.; et al. Evaluation of the association of PIK3CA mutations and PTEN loss with efficacy of trastuzumab therapy in metastatic breast cancer. Breast Cancer Res. Treat. 2011, 128, 447-456. [CrossRef] [PubMed]

158. Esteva, F.J.; Guo, H.; Zhang, S.; Santa-Maria, C.; Stone, S.; Lanchbury, J.S.; Sahin, A.A.; Hortobagyi, G.N.; Yu, D. PTEN, PIK3CA, p-Akt, and p-p70s6k status: Association with trastuzumab response and survival in patients with HER2-positive metastatic breast cancer. Am. J. Pathol. 2010, 177, 1647-1656. [CrossRef] [PubMed]

159. Dave, B.; Migliaccio, I.; Gutierrez, M.C.; Wu, M.F.; Chamness, G.C.; Wong, H.; Narasanna, A.; Chakrabarty, A.; Hilsenbeck, S.G.; Huang, J.; et al. Loss of phosphatase and tensin homolog or phosphoinositol-3 kinase activation and response to trastuzumab or lapatinib in human epidermal growth factor receptor 2-overexpressing locally advanced breast cancers. J. Clin. Oncol. 2011, 29, 166-173. [CrossRef] [PubMed]

160. Musolino, A.; Naldi, N.; Bortesi, B.; Pezzuolo, D.; Capelletti, M.; Missale, G.; Laccabue, D.; Zerbini, A.; Camisa, R.; Bisagni, G.; et al. Immunoglobulin $\mathrm{g}$ fragment c receptor polymorphisms and clinical efficacy of trastuzumab-based therapy in patients with HER-2/NEU-positive metastatic breast cancer. J. Clin. Oncol. 2008, 26, 1789-1796. [CrossRef] [PubMed]

161. Tamura, K.; Shimizu, C.; Hojo, T.; Akashi-Tanaka, S.; Kinoshita, T.; Yonemori, K.; Kouno, T.; Katsumata, N.; Ando, M.; Aogi, K.; et al. FcGammar2A and 3A polymorphisms predict clinical outcome of trastuzumab in both neoadjuvant and metastatic settings in patients with HER2-positive breast cancer. Ann. Oncol. 2011, 22, 1302-1307. [CrossRef] [PubMed]

162. Gong, C.; Yao, Y.; Wang, Y.; Liu, B.; Wu, W.; Chen, J.; Su, F.; Yao, H.; Song, E. Up-regulation of MIR-21 mediates resistance to trastuzumab therapy for breast cancer. J. Biol. Chem. 2011, 286, 19127-19137. [CrossRef] [PubMed]

163. Jung, S.T.; Kelton, W.; Kang, T.H.; Ng, D.T.; Andersen, J.T.; Sandlie, I.; Sarkar, C.A.; Georgiou, G. Effective phagocytosis of low HER2 tumor cell lines with engineered, aglycosylated IGG displaying high FCgammariia affinity and selectivity. ACS Chem. Biol. 2013, 8, 368-375. [CrossRef] [PubMed]

164. Mercogliano, M.F.; De Martino, M.; Venturutti, L.; Rivas, M.A.; Proietti, C.J.; Inurrigarro, G.; Frahm, I.; Allemand, D.H.; Deza, E.G.; Ares, S.; et al. Tnfalpha-induced mucin 4 expression elicits trastuzumab resistance in HER2-positive breast cancer. Clin. Cancer Res. 2017, 23, 636-648. [CrossRef] [PubMed]

165. Nahta, R.; O'Regan, R.M. Evolving strategies for overcoming resistance to HER2-directed therapy: Targeting the PI3K/Akt/mTOR pathway. Clin. Breast Cancer 2010, 10 (Suppl. 3), S72-S78. [CrossRef] [PubMed]

166. Wilks, S.T. Potential of overcoming resistance to HER2-targeted therapies through the PI3K/Akt/mTOR pathway. Breast 2015, 24, 548-555. [CrossRef] [PubMed]

167. Garcia-Garcia, C.; Ibrahim, Y.H.; Serra, V.; Calvo, M.T.; Guzman, M.; Grueso, J.; Aura, C.; Perez, J.; Jessen, K.; Liu, Y.; et al. Dual mtorc1/2 and HER2 blockade results in antitumor activity in preclinical models of breast cancer resistant to anti-HER2 therapy. Clin. Cancer Res. 2012, 18, 2603-2612. [CrossRef] [PubMed]

168. O’Brien, N.A.; McDonald, K.; Tong, L.; von Euw, E.; Kalous, O.; Conklin, D.; Hurvitz, S.A.; di Tomaso, E.; Schnell, C.; Linnartz, R.; et al. Targeting PI3K/mTOR overcomes resistance to HER2-targeted therapy independent of feedback activation of Akt. Clin. Cancer Res. 2014, 20, 3507-3520. [CrossRef] [PubMed]

169. Rexer, B.N.; Chanthaphaychith, S.; Dahlman, K.; Arteaga, C.L. Direct inhibition of PI3K in combination with dual HER2 inhibitors is required for optimal antitumor activity in HER2+ breast cancer cells. Breast Cancer Res. 2014, 16, R9. [CrossRef] [PubMed]

170. Elster, N.; Cremona, M.; Morgan, C.; Toomey, S.; Carr, A.; O'Grady, A.; Hennessy, B.T.; Eustace, A.J. A preclinical evaluation of the PI3K alpha/delta dominant inhibitor bay 80-6946 in HER2-positive breast cancer models with acquired resistance to the HER2-targeted therapies trastuzumab and lapatinib. Breast Cancer Res. Treat. 2015, 149, 373-383. [CrossRef] [PubMed]

171. Agus, D.B.; Akita, R.W.; Fox, W.D.; Lewis, G.D.; Higgins, B.; Pisacane, P.I.; Lofgren, J.A.; Tindell, C.; Evans, D.P.; Maiese, K.; et al. Targeting ligand-activated ERBB2 signaling inhibits breast and prostate tumor growth. Cancer Cell 2002, 2, 127-137. [CrossRef] 
172. Nahta, R.; Hung, M.C.; Esteva, F.J. The HER-2-targeting antibodies trastuzumab and pertuzumab synergistically inhibit the survival of breast cancer cells. Cancer Res. 2004, 64, 2343-2346. [CrossRef] [PubMed]

173. Takai, N.; Jain, A.; Kawamata, N.; Popoviciu, L.M.; Said, J.W.; Whittaker, S.; Miyakawa, I.; Agus, D.B.; Koeffler, H.P. 2C4, a monoclonal antibody against HER2, disrupts the HER kinase signaling pathway and inhibits ovarian carcinoma cell growth. Cancer 2005, 104, 2701-2708. [CrossRef] [PubMed]

174. Sak, M.M.; Szymanska, M.; Bertelsen, V.; Hasmann, M.; Madshus, I.H.; Stang, E. Pertuzumab counteracts the inhibitory effect of ErbB2 on degradation of ErbB3. Carcinogenesis 2013, 34, 2031-2038. [CrossRef] [PubMed]

175. Khalil, H.S.; Langdon, S.P.; Goltsov, A.; Soininen, T.; Harrison, D.J.; Bown, J.; Deeni, Y.Y. A novel mechanism of action of HER2 targeted immunotherapy is explained by inhibition of NRF2 function in ovarian cancer cells. Oncotarget 2016, 7, 75874-75901. [CrossRef] [PubMed]

176. Swain, S.M.; Clark, E.; Baselga, J. Treatment of HER2-positive metastatic breast cancer. N. Engl. J. Med. 2015, 372, 1964-1965. [CrossRef] [PubMed]

177. Ponde, N.; Brandao, M.; El-Hachem, G.; Werbrouck, E.; Piccart, M. Treatment of advanced HER2-positive breast cancer: 2018 and beyond. Cancer Treat. Rev. 2018, 67, 10-20. [CrossRef] [PubMed]

178. Scheuer, W.; Friess, T.; Burtscher, H.; Bossenmaier, B.; Endl, J.; Hasmann, M. Strongly enhanced antitumor activity of trastuzumab and pertuzumab combination treatment on HER2-positive human xenograft tumor models. Cancer Res. 2009, 69, 9330-9336. [CrossRef] [PubMed]

179. Yamashita-Kashima, Y.; Iijima, S.; Yorozu, K.; Furugaki, K.; Kurasawa, M.; Ohta, M.; Fujimoto-Ouchi, K. Pertuzumab in combination with trastuzumab shows significantly enhanced antitumor activity in HER2-positive human gastric cancer xenograft models. Clin. Cancer Res. 2011, 17, 5060-5070. [CrossRef] [PubMed]

180. Faratian, D.; Zweemer, A.J.; Nagumo, Y.; Sims, A.H.; Muir, M.; Dodds, M.; Mullen, P.; Um, I.; Kay, C.; Hasmann, M.; et al. Trastuzumab and pertuzumab produce changes in morphology and estrogen receptor signaling in ovarian cancer xenografts revealing new treatment strategies. Clin. Cancer Res. 2011, 17, 4451-4461. [CrossRef] [PubMed]

181. Sims, A.H.; Zweemer, A.J.; Nagumo, Y.; Faratian, D.; Muir, M.; Dodds, M.; Um, I.; Kay, C.; Hasmann, M.; Harrison, D.J.; et al. Defining the molecular response to trastuzumab, pertuzumab and combination therapy in ovarian cancer. Br. J. Cancer 2012, 106, 1779-1789. [CrossRef] [PubMed]

182. Richard, S.; Selle, F.; Lotz, J.P.; Khalil, A.; Gligorov, J.; Soares, D.G. Pertuzumab and trastuzumab: The rationale way to synergy. An. Acad. Bras. Cienc. 2016, 88 (Suppl. 1), 565-577. [CrossRef] [PubMed]

183. Goltsov, A.; Deeni, Y.; Khalil, H.S.; Soininen, T.; Kyriakidis, S.; Hu, H.; Langdon, S.P.; Harrison, D.J.; Bown, J. Systems analysis of drug-induced receptor tyrosine kinase reprogramming following targeted mono- and combination anti-cancer therapy. Cells 2014, 3, 563-591. [CrossRef] [PubMed]

184. Fuentes, G.; Scaltriti, M.; Baselga, J.; Verma, C.S. Synergy between trastuzumab and pertuzumab for human epidermal growth factor 2 (HER2) from colocalization: An in silico based mechanism. Breast Cancer Res. 2011, 13, R54. [CrossRef] [PubMed]

185. Fabi, A.; Mottolese, M.; Segatto, O. Therapeutic targeting of ErbB2 in breast cancer: Understanding resistance in the laboratory and combating it in the clinic. J. Mol. Med. 2014, 92, 681-695. [CrossRef] [PubMed]

186. Ghosh, R.; Narasanna, A.; Wang, S.E.; Liu, S.; Chakrabarty, A.; Balko, J.M.; Gonzalez-Angulo, A.M.; Mills, G.B.; Penuel, E.; Winslow, J.; et al. Trastuzumab has preferential activity against breast cancers driven by HER2 homodimers. Cancer Res. 2011, 71, 1871-1882. [CrossRef] [PubMed]

187. Junttila, T.T.; Akita, R.W.; Parsons, K.; Fields, C.; Lewis Phillips, G.D.; Friedman, L.S.; Sampath, D.; Sliwkowski, M.X. Ligand-independent HER2/HER3/PI3K complex is disrupted by trastuzumab and is effectively inhibited by the PI3K inhibitor GDC-0941. Cancer Cell 2009, 15, 429-440. [CrossRef] [PubMed]

188. Sakai, K.; Yokote, H.; Murakami-Murofushi, K.; Tamura, T.; Saijo, N.; Nishio, K. Pertuzumab, a novel her dimerization inhibitor, inhibits the growth of human lung cancer cells mediated by the HER3 signaling pathway. Cancer Sci. 2007, 98, 1498-1503. [CrossRef] [PubMed]

189. Hu, S.; Sun, Y.; Meng, Y.; Wang, X.; Yang, W.; Fu, W.; Guo, H.; Qian, W.; Hou, S.; Li, B.; et al. Molecular architecture of the ErbB2 extracellular domain homodimer. Oncotarget 2015, 6, 1695-1706. [CrossRef] [PubMed] 
190. Mohan, N.; Shen, Y.; Endo, Y.; ElZarrad, M.K.; Wu, W.J. Trastuzumab, but not pertuzumab, dysregulates HER2 signaling to mediate inhibition of autophagy and increase in reactive oxygen species production in human cardiomyocytes. Mol. Cancer Ther. 2016, 15, 1321-1331. [CrossRef] [PubMed]

191. Diessner, J.; Bruttel, V.; Becker, K.; Pawlik, M.; Stein, R.; Hausler, S.; Dietl, J.; Wischhusen, J.; Honig, A. Targeting breast cancer stem cells with HER2-specific antibodies and natural killer cells. Am. J. Cancer Res. 2013, 3, 211-220. [PubMed]

192. Lua, W.H.; Gan, S.K.; Lane, D.P.; Verma, C.S. A search for synergy in the binding kinetics of trastuzumab and pertuzumab whole and F(AB) to HER2. NPJ Breast Cancer 2015, 1, 15012. [CrossRef] [PubMed]

193. Verma, S.; Miles, D.; Gianni, L.; Krop, I.E.; Welslau, M.; Baselga, J.; Pegram, M.; Oh, D.Y.; Dieras, V.; Guardino, E.; et al. Trastuzumab emtansine for HER2-positive advanced breast cancer. N. Engl. J. Med. 2012, 367, 1783-1791. [CrossRef] [PubMed]

194. Baselga, J.; Coleman, R.E.; Cortes, J.; Janni, W. Advances in the management of HER2-positive early breast cancer. Crit. Rev. Oncol. Hematol. 2017, 119, 113-122. [CrossRef] [PubMed]

195. Cimino-Mathews, A.; Foote, J.B.; Emens, L.A. Immune targeting in breast cancer. Oncology 2015, 29, 375-385. [PubMed]

196. Geuijen, C.A.W.; De Nardis, C.; Maussang, D.; Rovers, E.; Gallenne, T.; Hendriks, L.J.A.; Visser, T.; Nijhuis, R.; Logtenberg, T.; de Kruif, J.; et al. Unbiased combinatorial screening identifies a bispecific IGG1 that potently inhibits HER3 signaling via HER2-guided ligand blockade. Cancer Cell 2018, 33, 922-936. [CrossRef] [PubMed]

(C) 2018 by the authors. Licensee MDPI, Basel, Switzerland. This article is an open access article distributed under the terms and conditions of the Creative Commons Attribution (CC BY) license (http:/ / creativecommons.org/licenses/by/4.0/). 